\title{
FACTORS EXPLAINING TRADE GROWTH AMONG THE FORMER SOVIET CENTRAL ASIAN COUNTRIES IN THE CONTEXT OF RECENT GLOBALIZATION PROCESSES
}

\author{
Mubinzhon Abduvaliev \\ University of the Basque Country UPV/EHU, \\ Tajik State University of Commerce \\ Ricardo Bustillo \\ University of the Basque Country UPV/EHU
}

\begin{abstract}
This paper examines the determinants of trade flows among the CIS countries after the signature of several free trade agreements in an attempt to create a trade bloc aimed at benefiting from the world globalization process. Furthermore, we test the extent to which the CIS countries' trade growth has been associated with Russian economic performance. Our findings suggest that free trade agreements have favoured the creation of trade amongst CIS countries. However, intra-regional trade has not soared due to geographical disadvantages or certain lack of governance quality. The Russian influence in the region appears to be declining; however, new linkages such as migration, remittances, finance and energy supply dependency have recently sustained the Russian relevance.
\end{abstract}

Keywords: globalization process, Commonwealth of Independent States, trade integration, landlockedness.

\section{Introduction}

The collapse of the Soviet Union ${ }^{1}$ was expected to lead to a major reorientation of each post-Soviet republic's trade pattern, since the politically determined commercial links under central planning had given rise to a substantial over-trading amongst the post-Soviet states (Grigoriou 2007). In the course of this process, the structures of these economies have been, at least partially, reoriented away from a single centralized command economy towards more decentralized and diversified economies, which respond to price signals and incentives. As a result, the strong interconnections between these economies weakened at the beginning of independence, whereas the links to the rest of the world strengthened following a pattern of trade creation and diversification (Viner 1950).

The transmission mechanism linking Russia's economic policy and performance to the CIS growth evolved considerably during the 1990s. The gradual integration of the CIS into the global economy changed the structure and strength of the CIS economic ties with Russia. In the beginning, the break-up of the Soviet Union and the subsequent collapse of the trade and payment systems along with the cessation of fiscal transfers from Moscow led to a substantial decline in the output throughout the region (Robson

Journal of Globalization Studies, Vol. 12 No. 2, November $202119-46$ DOI: $10.30884 / j o g s / 2021.02 .02$ 
2006). From that moment onwards, the traditional Russian influence on the CIS economic performance through trade appears to be declining, while new linkages such as migration, remittances, finance and political gains through the CIS dependency on the Russian energy supply and transit emerged. New commercial hubs, such as the European Union (EU) and China have become important trading partners for many CIS countries. Hence, the perception of Russia's regional economic influence should be nuanced in order to reflect these new realities.

Although the geographical destination of the CIS countries' exports of natural resources and raw materials has diversified, Russia remains both the largest import and export partner for all CIS countries. Economic pressure, energy dependency, multilateral groupings, diasporas and the reapplication of Russian cultural education are all used to sustain the old, but recently revived, fantasy of the Eurasian Economic Union ${ }^{2}$ (EEU) (Nixey 2012). Regaining political control over the post-Soviet space through the EEU is one of the main Russia's targets in the present moment. Russia could exert its political influence to hamper the full integration of the CIS countries into the world market by applying those different strategies. Regarding some CIS countries, we can mention the loss of sovereignty by Kazakhstan and Belarus after joining the EEU, which hinders their capability of independently managing their internal and external affairs (Falyakhov 2013). Other CIS countries such as Tajikistan, Moldova and Uzbekistan also strive to avoid the dependence on one state (Galstyan 2017). Nevertheless, these three countries feel that joining the EEU is inevitable, since millions of Tajik, Uzbek and Moldavian migrants are working in Russia and in the case of reluctance towards the EEU, Russia could exert its political influence to hinder these countries' economic development (Sebastian 1998; Europe and Central Asia Report \#240, 2016). However, despite the Russian political pressure and the poor level of institutional quality, which probably reduces their potential growth (Havrylyshyn et al. 1998; EBRD 2003; Freinkman et al. 2004), new initiatives for regional cooperation indicate that the CIS countries are aware of potential benefits from trade integration (Kurmanalieva and Vinokurov 2011). Promoting the trade flows amongst the CIS countries should thus be a policy priority for governments and international institutions. However, the intra-regional trade growth has faced some obstacles due to the low level of institutional quality even after signing different agreements aimed at creating a trade bloc among the former Soviet Central Asian countries.

The main objective of this paper is to examine the existing regional trade links between the CIS countries in order to shed light on both the determinants of the CIS bilateral trade flows and connection between economic growth in Russia and in eleven CIS countries.

We have used the gravity model to estimate the trade patterns of the twelve CIS countries covering the period from 1997 to 2014, including factors such as quality of countries' institutions, geographic disadvantages (landlockedness ${ }^{3}$ ), and the restrictiveness of the trade regime apart from a set of control variables. This study utilized an empirical model which is similar to the one used by Elborgh-Woytek (2003), Havrylyshyn and Al-Atrash (1998), Freinkman et al. (2004), or Babetskaia-Kukharchuk and Maurel (2004). Our empirical analysis has been carried out in order to test the following hypotheses:

$\mathrm{H} 1$ : Belonging to the same free trade agreement has provoked an increase in trade flows amongst the CIS countries. 
H2: Each country's particular institutions do play a role in explaining the trade flows amongst the CIS countries: countries with higher level of institutional quality demonstrate better trade performance.

H3: Geographic disadvantage (landlocked and poor infrastructure) impacts the trade amongst the CIS countries: the landlocked country's trade indices are lower.

H4: Russia's economic performance has a strong impact on the CIS countries' trade flows.

H5: Globalization has hardly favoured the trade growth among the CIS countries.

The paper proceeds as follows: in the next section, we provide a survey of the literature concerning the trade flows amongst the CIS countries. Section 3 describes some problems in the economic integration of the Soviet Central Asian countries and Russia in the context of globalization. Section 4 describes the basic economic features of the CIS countries. Section 5 presents inter-regional trade performance amongst the CIS countries, whereas Section 6 shows the methodology of the paper. Our econometric model and empirical results are explained in Section 7. The concluding section summarizes and discusses potential development implications.

\section{Literature Review of the Factors Driving the Trade Growth and Development}

Gains from trade are amongst the earliest and most enticing discussions in economics. No country in recent decades has achieved economic success, in terms of substantial increase in living standards for its people, without being open to the rest of the world (IMF 2001). In the 1990s, the Washington Consensus, based on the recommendation of the International Monetary Fund (IMF) and the World Bank (WB), regarded trade openness as essential factor for achieving a high level of economic growth (Washington Consensus 1993. According to the World Trade Organization (WTO 2008), openness and trade liberalization not only promote a country's exports and imports, but also stimulate economic activities of the private sector, attract foreign investment, reduce poverty rates, create employment and increase foreign earnings.

In spite of the wave of liberalization undertaken during the last three decades, the debate on the links and causality between trade openness and economic growth or income distribution is still an open issue (Rodriguez and Rodrik 2001). Utilizing different econometric techniques, many authors have attempted to determine whether increased openness leads to an economic expansion. Most empirical works dealing with openness and growth claim to find a positive association between economic integration and growth. For instance, David Dollar (1992) stated that open economies grew remarkably faster compared to closed economies during the period from 1976 to 1985 . Sachs and Warner (1995) argued that open developing and developed countries grew annually at 4.49 per cent and 2.29 per cent rates respectively, whereas closed economies grew at 0.69 per cent and 0.74 per cent. Edwards (1998), performing a survey of empirical literature, defended the positive effect of openness on economic growth and claimed that the trade-growth nexus was not only robust to the indicators of openness but also to functional forms, estimation techniques and periods. Jeffrey (1997) utilized a panel data set for 65 countries covering the period from 1985 to 1997 and concluded that a onepercent increase in trade-GDP ratio could raise per-capita income by at least 0.5 per cent. ${ }^{4}$

However, Rodriguez and Rodrik (2001) questioned the robustness of the studies proving the trade-growth positive relationship. They mainly criticized the inappropriate 
econometric techniques and the lack of control of other important determinants, an idea also supported by Baldwin (2003). Additionally, Rodriguez and Rodrik (2000) stated that this controversy is not about the positive or negative relationship between trade and growth, but that it is rather about the proper use of empirical procedures, as well as about their interpretation. Finally yet importantly, Hallak and Levinsohn (2004) stated that the regression framework is too simple to capture the relationship between trade policy and economic growth. ${ }^{5}$

Notwithstanding, free trade supporters dismissed Rodrik and Rodriguez's critiques. For instance, Bhagqati (2001) and Panagariya (2004), after having analyzed Rodrik and Rodriguez's view, asserted that their criticism is inconclusive. They concluded that the evidence from cross-country growth regressions is not that weak and therefore, outward-oriented policies cannot be rejected. Later Tung (2015), using a panel data set for 71 developing countries (1980-1990), concluded that there is a positive correlation between openness and economic growth, while Mendoza (2010) found a conditional relationship between trade and economic growth.

Although there is an abundant body of literature regarding the openness-trade nexus in many world regions, the CIS countries' case studies are scarce. Amongst them, Havrylyshyn and Al-Atrash (1998) stated that several CIS countries ${ }^{6}$ are becoming as open as similar market economies, but many others remain relatively closed. The closest nations ${ }^{7}$ to the EU are the most successful. Freinkman et al. (2004) concluded that the process of trade diversification in CIS- $7^{8}$ countries remains incomplete, especially amongst the lowincome CIS countries. However, according to Elborgh-Woytek (2003), openness has been falling since 1997 among the CIS countries and will likely increase if market reforms are carried out more ambitiously. Elborgh-Woytek analyzed developments in the structure of trade in the CIS countries during the period of 1993-2002, concluding that during those years, the CIS changed less than other transition economies because of geographical aspects, restrictions on trade, governance and corruption problems, weak infrastructure, lack of regional cooperation and political conflicts amongst the CIS countries. Similarly, Djankov and Freund (2000) explained home bias with Russia, through the introduction of high external tariffs and past links, such as infrastructure, business networks and production chains. Recently, Ian Babetskii et al. (2004) used cross-section data for the period spanning 1970-2004 finding that if the CIS countries accessed jointly the WTO, their total trade volume would increase by 50 per cent.

Whether a country should adopt a free-trade regime with neighbouring countries or not, is still a highly debated issue amongst experts. International trade theories, from Ricardo's comparative advantage model to the two-country endogenous growth models developed by Grossman and Helpman (1991) and Feenstra and Hanson (1996), can be considered a justification for the formation of free trade agreements (FTA). However, if we look at empirical studies about FTA effects on trade growth, we will find mixed results. For instance, Nobel laureate Jan Tinbergen (1962) was the first to publish an econometric study using the gravity equation for international trade flows, which included evaluating the effect of FTA dummy variables on trade. He found economically insignificant 'average treatment effects' of FTAs on trade growth. Similarly, Bergstrand (1985) and Frankel and Romer (1995) found an insignificant effect of the FTA on trade amongst European Community (EC) member countries, opposite to Aitken (1973), 
Abrams (1980) and Brada and Mendez (1985), who found a statistically significant effect on trade flows amongst the EC members. Baier and Bergstrand (2007), using panel data for 96 countries over 1960-2000, found that, on average, an FTA approximately doubles two members' bilateral trade flows after ten years.

Regarding the FTA effect on output and trade growth amongst the CIS countries, Francois and Manchin (2009) stated that a thorough FTA with the EU would not only reduce tariffs but also lead to an average 0.62 percent increase in the CIS countries' real income. Emerson et al. (2006) analyzed the FTA effect on the EU and Ukraine trade performance and argued that the overall welfare gain for Ukraine from the FTA with the EU would be above 10 per cent. Maliszewska (2008) stated that an FTA with the EU is expected to bring an increase of 3.38 per cent in Armenian GDP and 6.5 per cent in the Georgian GDP. In addition, they concluded that due to an FTA with the EU, Georgian exports were expected to increase by 13.5 per cent in five years. De Souza (2004) and Sulamaa and Widgren (2004), focusing on the Russian case, suggested that Russia would benefit from an FTA with the EU in case Russia improved its productivity through better institutions or received more inward FDI.

Other studies have identified that good institutions are the main key in enhancing economic growth. Therefore, liberal trade policies also need to be complemented with effective institutional improvement policies to ensure a longer-term effect on growth (Lee and Swagel 1997; Rodrik 2006; Anderson and van Wincoop 2003; Elborgh-Woytek 2003; Acemoglu and Robinson 2006).

North (1981) and Acemoglu and Robinson (2002) define institutions as a cluster of social arrangements that include constitutional and social limits on politicians' and elites' power, provisions for mediating social cleavages, strong property rights enforcement, the rule of law, a minimum amount of equal opportunities and relatively broadbased access to education.

Hence, some authors have revealed that a better quality of institutions could enhance economic growth. ${ }^{9}$ For instance, Burnside and Dollar (2000) using a panel data set for 57 developing countries (1970-1993), and Vijayaraghavan and Ward (2001) for 43 developing countries (1975-1990), concluded that institutional qualities such as property rights, governance, government size and political freedom enhance economic growth.

The transition of post-Soviet states into market economies was a phenomenon that inspired rethinking the role of institutions in reform programmes and economic performance. Amongst other empirical studies, the European Bank for Reconstruction and Development (2003) reports that a low quality of economic institutions is to be blamed for the "trade gap" 10 of 60 per cent between the CIS countries and the EU. Grinsberg and Mertenz (2005) state that because of low institutional quality in the post-Soviet states, over 1,000 official agreements have been passed to regulate the trade within the CIS, but only about 10 per cent are effective.

However, institutional quality and trade barriers are not the most relevant factors for trade performance amongst developing countries, since remoteness, poor road $/ \mathrm{maritime}$ infrastructure and landlockedness appear to be the most important causes of trade slow growth. ${ }^{11}$ According to Beilock et al. (1996), each border crossing within the post-Soviet states' region implies over a 400 USD increase in per truck-load freight rates. However, we should take into account that 84.7 per cent of total freight transports in Central Asian 
countries were carried out by rail during 2015 (CISSTAT 2017) and therefore it is too difficult to measure the high negative impact of the low infrastructure level in Central Asian trade relations. In contrast, Limao and Venables (2001) suggested that distance explains only 10 per cent of the change in transport costs, whereas poor road infrastructure explains 40 per cent in coastal countries and 60 per cent in landlocked countries. Grigoriou (2007), using panel data for 167 countries, including Central Asian ones over the period of 1992-2004, concluded that an improvement in infrastructure of Central Asian countries would raise exports by 65 per cent and imports by 8.6 per cent. According to the UNOHRLLS $^{12}$ (2013) report, most CIS countries reveal transport costs that are up to 40 per cent higher than those of a representative coastal economy.

The literature has explained the link between landlockedness, transport costs, infrastructure and growth. For instance, Bougheas et al. (1999) and McKellar et al. (2000) developed the theoretical relationship between infrastructure and trade growth, whereas Radelet and Sachs (1998) and Raballand (2003), who carried out a survey on the impact of landlockedness on trade, provided empirical evidence.

To summarize, we acknowledge that most studies confirm the existence of a positive link between trade and growth, but the validity of the results could be questioned based on robustness tests. However, the presence of econometric and measurement problems does not permit a thorough rejection of the observed positive link between trade openness and economic growth. Trade policies ought to be properly complemented with the improvement of institutions inside countries to optimize gains from trade.

There have been, however, some political obstacles for the establishment of institutions over the last decades. Additionally, as shown by the above-mentioned empirical literature, the highest priority for the CIS countries lies in the improvement of their transport infrastructure, especially amongst landlocked countries, which would help contribute favouring better export performance amongst the CIS countries.

\section{Problems of the Economic Integration of Central Asian Countries in the Context of Globalization}

During the last decades, the globalization of the world economy has developed quite quickly. One of the mostly widespread considerations, regarding globalization, views it as an irreversible process imposed upon the world by some countries and institutions. Furthermore, globalization as an increasingly free flow of ideas, people, goods, services, and capital has led to a deeper integration of economies and societies (IMF 2002). Nevertheless, globalization is also far from being uncontroversial since economic theory does not provide a clear answer for the effect of globalization on growth. On the one hand, many authors claim that there is a positive relationship between globalization and economic development. There is, however, little evidence supporting this statement. Mrak (2000) claims that the world GDP growth rates in the 1980s and 1990s have declined since the 1970s when financial liberalization started to grow. Brethelot (1999) asserts that the share of investment over the world GDP has generally fallen, suggesting a lower willingness to undertake long-term investments. Furthermore, Hoffmann (2002) stated that globalization and world trade created a global market, but it did not lead to the establishment of a global government or global society. Freinkman et al. (2004) analysed ${ }^{13}$ selected CIS countries finding that low income economies among the CIS countries have been performing on average just marginally better than 
other low-income countries and, overall, they have been falling behind the countries that benefit the most from globalization.

The effect of globalization is a highly uneven process also among the former Soviet Central Asian countries. After gaining independence in 1991, the CIS countries adopted economic openness as the main basic strategy for their economic growth. Due to difficulties in accessing global markets, trade amongst the CIS countries has become of paramount relevance. One of the most important factors of economic development is foreign trade, and Central Asian economies should seek a higher volume of intra-regional trade. Almost all world regions have enjoyed from the creation of regional organizations since the end of the Cold War; however, regional cooperation among the Central Asian countries remains unsuccessful. As a result, Mattli (1999) argues that the EU members' intraregional trade reaches more than 60 per cent of the total exports and imports flows, as the main driver for European integration comes from comparative advantages and economies of scale inside the single market. On the contrary, the share of intraregional trade within Central Asia is only about 10 per cent. Intra-regional trade among the Central Asian countries has been even declining since the dissolution of the Soviet Union at the beginning of the 1990s. Figure 1 shows the trade turnover of Kyrgyzstan and Tajikistan drastically reduced to $45-50$ per cent in the last two decades. Following Uzbekistan's trade share falling to 20-25 per cent, while Kazakhstan stands out as the least regionally integrated country, because its intraregional trade share declined up to a modest 10-15 per cent from the 1990s to 2017 (see Figure 1).
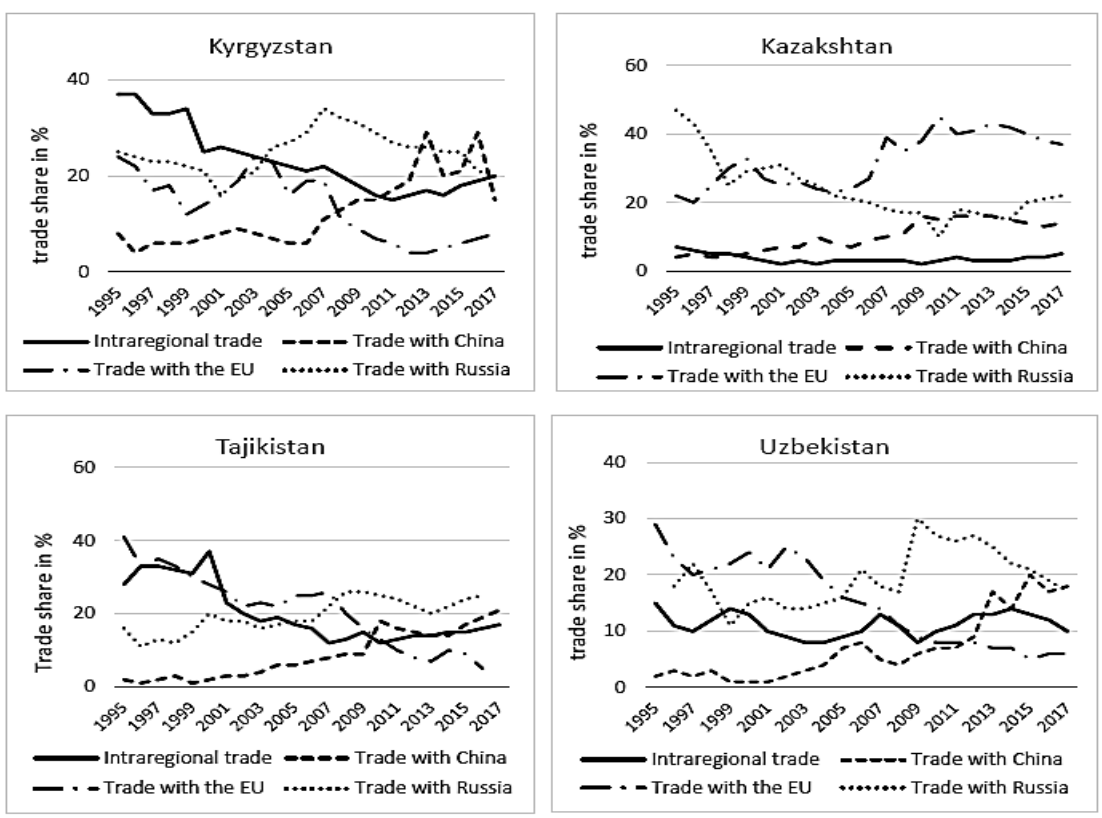

Fig. 1. Trade turnover of Central Asian countries

Note: Turkmenistan: Turkmenistan is not included due to the lack of reliable trade data.

Source: UN Comtrade database (comtrade.un.org). The Statistical Agency of Tajikistan (www.stat.tj/ru). 
There are significant barriers to trade in Central Asia in terms of trade policy, difficulties in transport and transit systems, as well as certain lack of trade complementariness. The Asian Development Bank (2010) claims that the most notable barriers in Central Asian region are a complex tariff schedule and the relatively high tariffs, the frequent and unpredictable changes in the tariff schedule or the high level of protectionism (i.e. high implicit tariffs in the form of taxes that are levied on imported goods but not on domestically produced goods). Furthermore, the EU's large agricultural subsidies to their farmers constitute a significant barrier for the Central Asian countries' exports to the EU. Notably, long and unpredictable transit times have constrained exports of time-sensitive goods and manufactured products with relatively low profit margins more than exports of primary commodities, which are not time-sensitive and can be transported in bulk at relatively low costs (Raballand et al. 2005). Wang (2014) asserts that Central Asian countries have relatively similar commodity-dependent economies and they produce and export many of the same items and therefore need to look for trade partners beyond their immediate neighbours, therefore they have repeatedly deployed protectionist measures against each other. The literature so far explains hysteresis in the former Soviet Union trade by remoteness and landlockedness (Hamilton and Winters 1992; Djankov and Freund 2002; Grafe, Raiser and Sakatsume 2005), distance (Fidrmuc and Fidrmuc 2003), poor access to markets and incomplete reforms (Havrylishin and Al-Atrash 1998), or weak institutions (Babetskaia-Kukharchuk and Maurel 2004).

For instance, Jan Fidrmuc and Jarko Fidrmuc (2003) estimated that the former Soviet Union states traded 43 times more between each other than predicted by GDP and distance. Raballand (2003), who analyzed the effect of landlockedness ${ }^{14}$ on trade in the case of Central Asian countries over the period of 1995-1999, found that landlockedness reduces their trade by more than 80 per cent. Limao and Venables (2001) and Hogan-Brun (2005) highlighted the high impact of remoteness and poor infrastructures on trade costs. Central Asian economies are dependent on the export of agricultural products and a few commodities such as gas and oil to extra-regional markets. Moreover, they all share the fundamental infrastructure problems of landlocked countries at the periphery of the global market (Myant and Drahokoupil 2008). Krapohl and Visileva-Dienes (2019) claim that Central Asian countries could improve their trade infrastructure and their share in the global market considerably, in case they cooperated with each other.

Whereas intra-regional trade is low in Central Asia, trade dependence on external actors, foremost Russia but also increasingly China, is high. Russia has been the most important trading partner for Central Asia since the early 1990s and at least up until the financial crisis of 2008/9 (Jenish 2015). Russia is the main bridge between Central Asian countries and Europe: 70 per cent of Central Asian exports reach Europe through Russia (Krapohl and Visileva-Dienes 2019). Moreover, Central Asian countries are interested in the access to Russian financial resources, discounted energy prices and free movement of labour, which leads to high remittances flows from migrants (Spechler 2002; Abduvaliev and Bustillo 2020). During the last decades, the cross border financial transactions and labor-remittance flows between Russia and these countries have become increasingly important and Russia appears to influence regional growth mainly through the remittance channel and less through the financial channel. Russia, as the 
main destination for migrants from the CIS region, accumulates 88 per cent of the CIS migrants (CISSTAT 2017), where Armenia, Azerbaijan, Belarus, Georgia, Kyrgyzstan, Moldova, Tajikistan, Turkmenistan, Uzbekistan and Ukraine are net remittancesreceiving countries. Long before the Russian economic crisis started in 2014, related to the Western economic sanctions against Russia over the Ukraine Crisis in mid-2014, the labour migrants constituted approximately 49.6 per cent of Tajikistan's GDP, 38.1 per cent of Kyrgyzstan's GDP, and 16 per cent of Uzbekistan's GDP (World Bank 2015). Still, cooperation with China is crucial for the Central Asian economies in terms of trade relation. Although, crisis in 2008/9 deteriorated cooperation between Russian and Central Asian countries, the Chinese trade share to Central Asian countries did not decline within the crisis both within financial crisis in 2008-2009 and the ongoing financial crisis since 2014. Even though Russia still remains the most important trading partner for Kazakhstan (after the EU), China is increasingly becoming an economic driver of the region that has already caught up in the case of Kyrgyzstan, Tajikistan, Turkmenistan and Uzbekistan (Stronski and Ng 2018). In recent years, China has been developing infrastructure projects in five Central Asian countries under the Belt and Road Initiative. The region is being transformed by China's infrastructure investment, with the launch of railway logistics routes connecting Central Asia and Europe, and the development of highways, oil and gas pipelines, transmission networks, and optical fibre cables (Kitade 2019). Natural resources as well as their strategic location, especially their proximity to China, could serve as a good platform for the future development of Central Asian economies.

In consequence, we must highlight that the CIS intra-regional trade has not developed as in other regions. Most countries in Central Asia are establishing a closer trade relation with other nations outside the CIS (Krapohl and Vasilieva-Dienes 2019) because of the factors discussed above. Therefore, we can at least confirm the fact that the ongoing globalization has not created a high volume of trade inside the region, but on the contrary, it has connected these nations with other external partners such as China or the EU, thus supporting the fifth hypothesis put forward in the introduction.

\section{Stylized Facts about Economic Performance amongst the CIS Countries}

The economic dependence of the CIS countries mostly divides them into the following two categories:

1. Net oil and gas exporters.

2. Countries heavily dependent on migrant remittances and foreign aid (Official Development Assistance, ODA).

The CIS countries dispose of a significant endowment of natural resources accounting for nearly 5.5-5.7 per cent of global supplies of oil and 11.4-11.6 per cent of natural gas resources (CISSTAT 2017) where Azerbaijan, Kazakhstan and Turkmenistan are the main oil and gas exporting countries in the CIS region, excluding Russia.

The CIS countries that belong to the second category of economic dependence reveal data of remittances between 5 and 43 per cent and ODA 2.1-7.8 per cent of GDP, respectively (World Bank 2016a). 


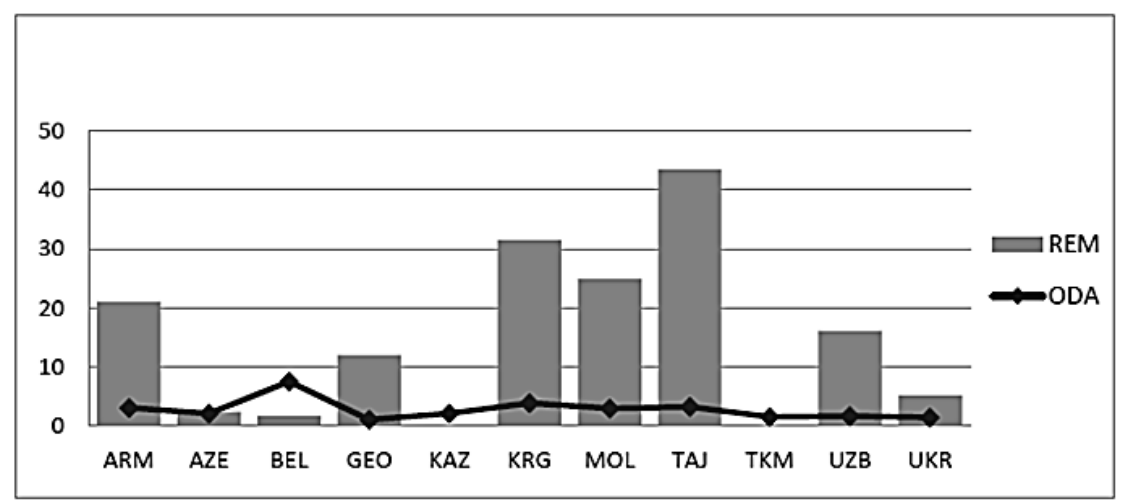

Fig. 2. The CIS countries: Remittances and ODA, \% GDP, 2015

Source: World Bank 2015.

Note: The data for Uzbekistan and Turkmenistan have been obtained from the Central Bank of Russia.

Figure 2 indicates that migrants' remittances as a ratio to GDP exceed ODA in most CIS countries. The USA, Germany, Turkey, Japan, Switzerland and France are the main ODA donors for the CIS countries (OECD/DAC 2015).

From 2000 to 2014, all CIS countries except Kyrgyzstan, Georgia and Ukraine registered strong economic growth. From 2005 to 2010, some CIS countries (Kyrgyzstan; from 2008 to 2009, Georgia; and from 2012 to 2014, Ukraine) have suffered from socio-political disturbances leading to disruptions in economic activity and changes in leadership. Despite the relatively weaker economic performance of these three countries, the average annual growth rate of the rest of the CIS countries was 6.1 per cent during the period of 1998-2016 (see Figure 3).

According to the Heritage Foundation and Index of Economic Freedom (2014), all CIS countries substantially increased their economic freedom positions. This improvement may have helped promote economic growth amongst these countries.

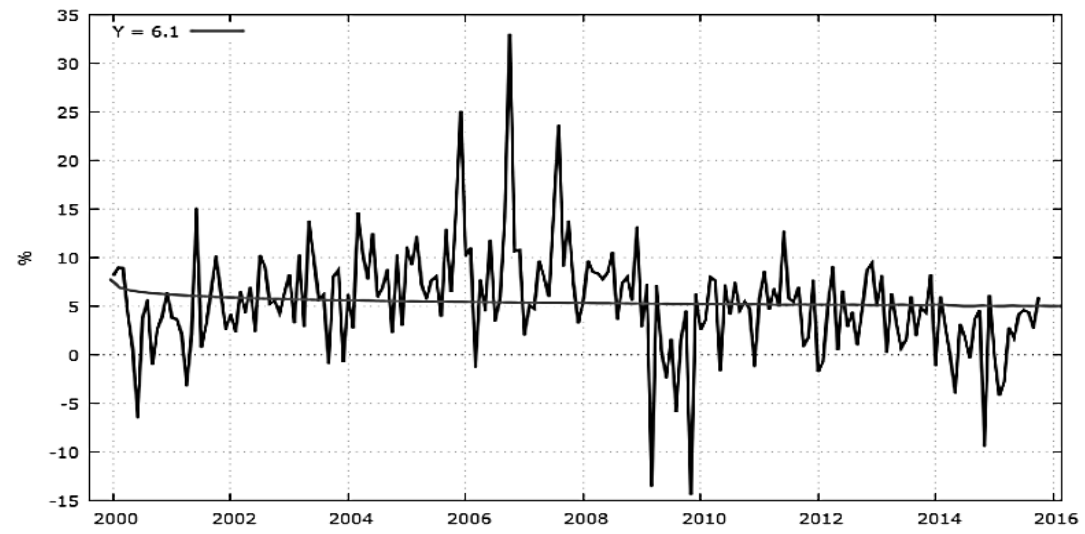

Fig. 3. CIS 11 annual average growth, 1998-2015

Source: World Economic Factbook, 2016a. 
If we look at the recent economic behaviour of the CIS countries, we will find that they experienced four crises since the collapse of the USSR (Figure 4).

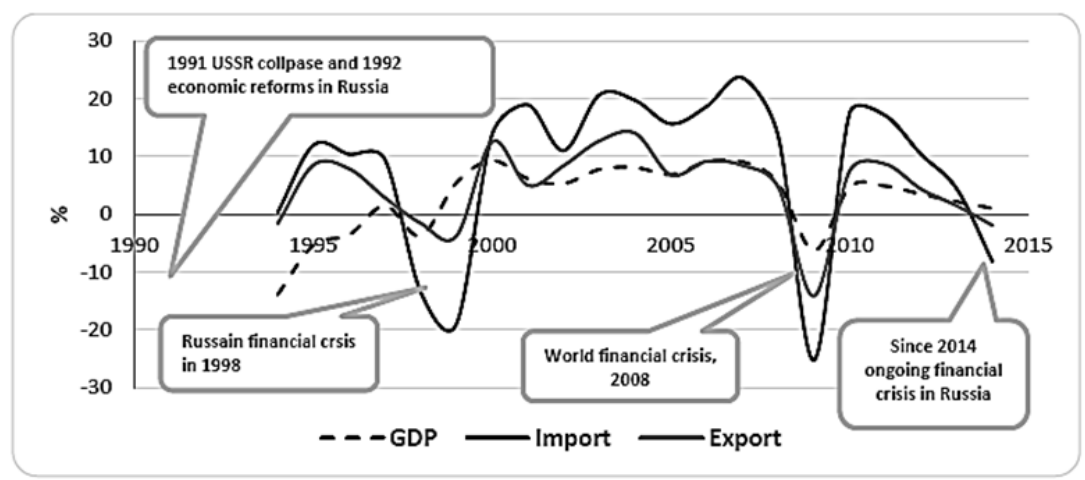

Fig. 4. The CIS countries: GDP, Exports and Imports (annual real growth), 1994-2014

Note: Per cent change of gross domestic product, constant prices, volume of export and import of goods and services.

Source: UNCTAD (2007), World Bank (2010), IMF (2015a).

The most relevant cause of the last crisis in Russia is mainly associated with the international economic sanctions imposed by Western countries, following the Russian annexation of Crimea (Ukraine). Sanctions provoked a negative effect on Russian crude oil prices and led to a devaluation of the ruble against the US dollar (Dreger et al. 2015). This reduced the migrant remittances transferred from Russia to the CIS countries.

In 2014, the CIS countries economic growth dropped from 1.25 per cent to 5.25 per cent respectively, driven, in part, by lower commodity prices and Russia economic slowdown (IMF 2015b), which has a close relationship with the CIS region through remittances, trade and the volume of investment (see Figure 5).

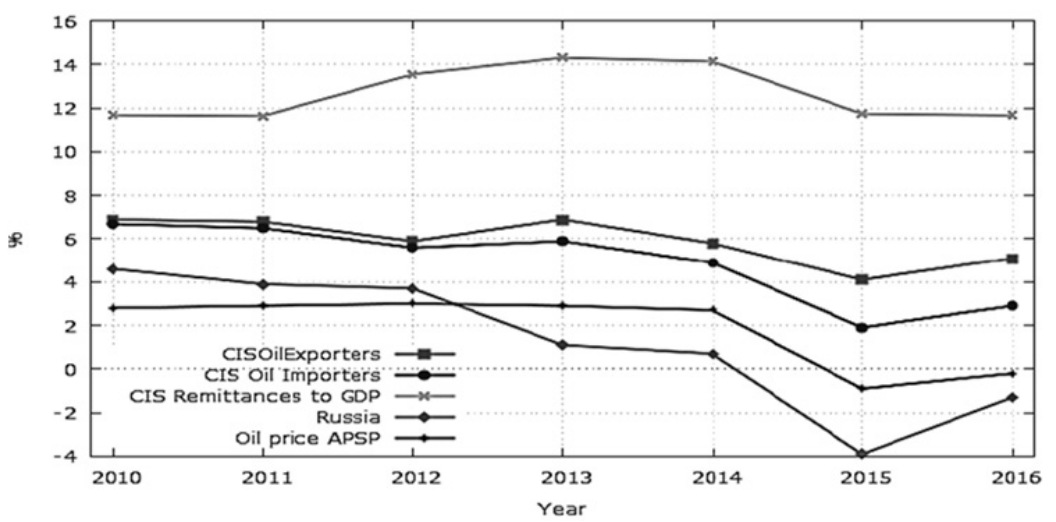

Fig. 5. Relationship between economic growth of CIS countries and Russian real GDP growth (Annual percent change)

Source: IMF Databases, 2017.

Note: * CIS oil exporters: UZB, KAZ, TKM, AZE.

** CIS oil importers: KGZ, ARM, TJK, GEO, UKR, BEL and MOL. 
The lower Russian oil prices have been amplified by a slowdown in Kazakhstan and Azerbaijan domestic oil production, while delays in the development of new Kazakh oil fields have resulted in the decline of the CIS oil exports by 2 percentage points to 3.5 per cent in 2015 (IMF 2016). Imports from Russia, including energy imports, constitute more than 5 per cent of GDP for most CIS countries. For a number of countries (Armenia, Belarus, Moldova and Ukraine), energy imports from Russia exceeded 23 per cent of their total energy consumption in 2016 (CBR 2017).

In the CIS, the oil importers' domestic demand is weakened by declining remittances, as remittances are the key channel of transmission of shocks from Russia to the CIS oil importers. The World Bank Development Prospects Group (World Bank 2016b) reports that three CIS countries have ranked first, second and fourth amongst the top ten remittances recipient countries in the world according to the ratio of remittances to GDP. Remittances constitute about 40 per cent of GDP in Tajikistan, 28 per cent in the Kyrgyz Republic, 21 per cent in Moldova and 18 per cent of GDP in Armenia as of 2016, with the bulk of these remittances originating in Russia. The Bank of America Merrill Lynch (2013) reported that a reduction of Russia's GDP by 1 per cent would reduce remittances inflows to Central Asian countries by 5 per cent.

Amongst the CIS countries, the situation fluctuated more after the USSR dissolution, and, almost two decades after independence from the Soviet Union, they have developed healthier deeper links with the Russian economy. This is perceptible, despite the geographical tension and sanctions that have sharply decreased the oil price in Russia since late 2014, resulting in negative spillovers (trade, remittances, FDI) on the CIS countries. An ongoing Russian crisis is an obvious example of how geopolitical risk is real and, in fact, can dramatically change a country's economy, particularly in Central Asian and Caucasian countries. The Russian politicians' decisions might not only result in circumstances that sink their own country's economy, but could also make the lives worse off for residents of other countries who have economic and socio-cultural ties with Russia.

\section{Inter-Regional Trade Performance and FTA amongst the CIS Countries}

The CIS countries are suffering the effects of a changing regional trade relationship. According to Head, Mayer and Ries (2010) opinion about post-colonial ties, a country's trade with their colonizer typically falls by 60 per cent and with siblings by 20 per cent after thirty years of independence. However, after 27 years of independence, the relationship between the CIS economies and Russian development, overall, through trade, financial and remittance channels is still strong (Table 1). The aim of this paper is not to test Head, Mayer and Ries's findings, but rather to explore the extent to which Russian economic performance has a strong impact on neighbouring CIS countries. The CIS countries have not yet managed to achieve considerable success in opening markets and in coordination of macroeconomic policies. 
CIS links with Russia, 2016

Table 1

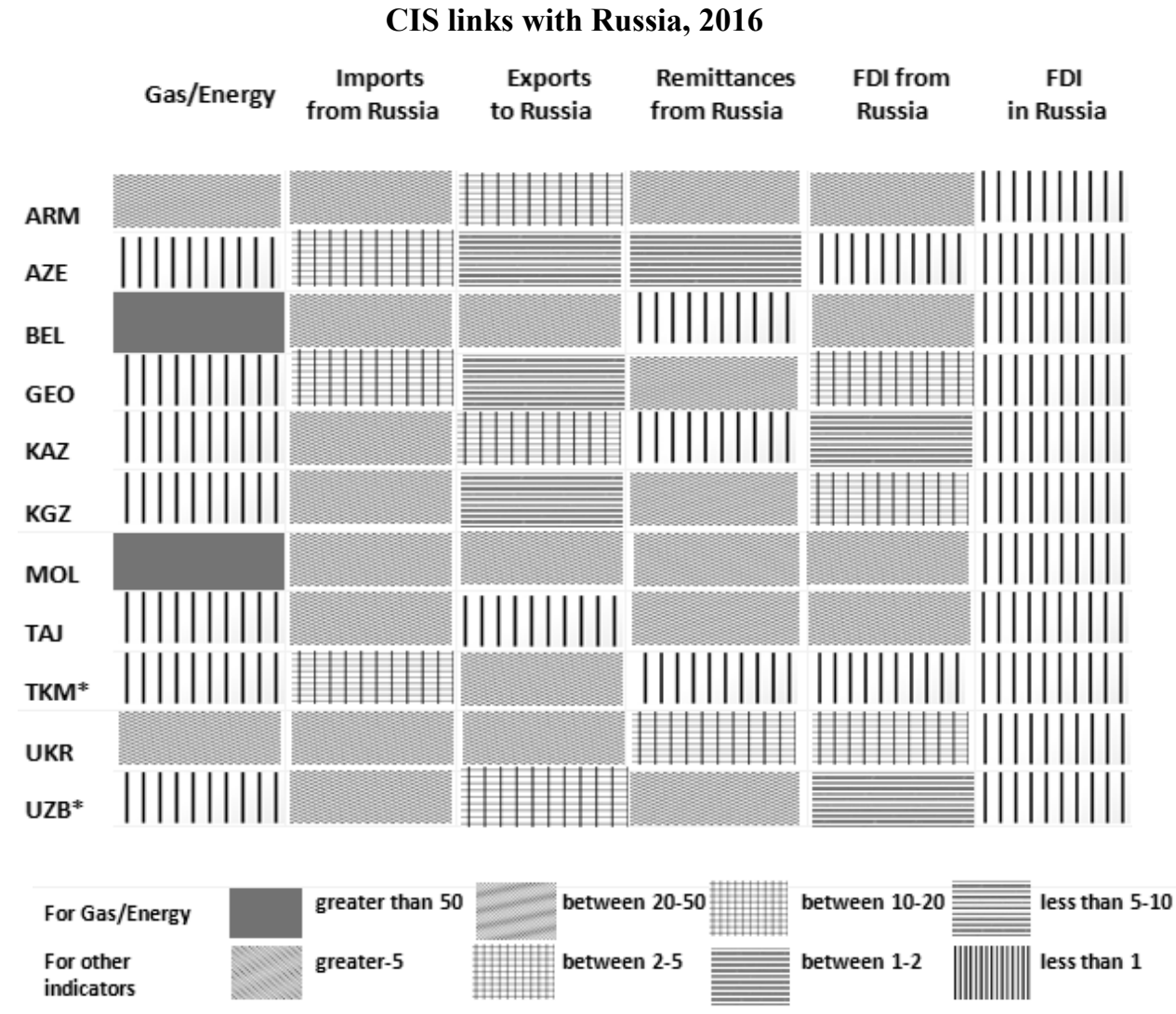

Source: IMF Database, 2017. (*) Gas exports to Russia; Gas/energy imports from Russia are scaled by country' energy consumption; other variables are scaled by GDP. Turkmenistan is an associate member of the CIS; Georgia used to be the CIS member (1993-2009) and Ukraine 1993-2014.

The IMF (2015b) reports that the trade links with Russia are generally weaker mostly in Central Asian countries, although for some CIS countries, trade exposure is still considerable. 'In addition, indirect spillovers through confidence effects and common investor linkages could be substantial, which is difficult to quantify' (Stepanyan et al. 2015). FDI is another important channel of spillovers from Russia, which is highly relevant for the CIS countries.

The trade volume of Russia with the CIS increased since 2001. The maximum value of Russia's trade surplus reached $\$ 33$ billion in 2008 , in contrast with $\$ 3.8$ billion in 1994. After the 2009 downturn, Russia remained a large net exporter, although the trade surplus decreased by $\$ 8$ billion (Andreev 2010; CISSTAT 2017) Notwithstanding, Russia is an important export destination and remains a relevant niche market for the CIS countries. For instance, Belarus and Turkmenistan have the largest exposure, with exports to Russia exceeding 10 per cent of GDP (IMF 2015b). Russia accounts for about half of non-oil exports for Azerbaijan, and Armenian food products have been a source 
of dynamism for the Russian economy, while a quarter of Moldova's agriculture exports were destined for Russia in 2015 (IMF 2016). Kazakhstan is still the main Russia's trading partner in iron, manganese, copper and chromium ores and concentrates, aluminium, coal, ferrous metals and uranium (Basargin 2012). Russia accounts for about a quarter of Turkmenistan's and Uzbekistan's gas exports (down from around 70 per cent during the global financial crisis). Imports from Russia, including energy imports, constitute more than 5 per cent of GDP for most CIS countries and energy imports from Russia to Armenia, Belarus, Moldova, Tajikistan and Ukraine exceeded 20 per cent of their total energy consumption (IMF 2015a). However, some CIS oil importing countries may not benefit from the lower price provided by Russia, since contracts on gas supply are usually long term and, in some cases, with fixed prices over several years.

The current Russian financial crisis has produced adverse spillovers to the CIS oil importers that account for more than 2.5 percentage points of downward growth, while for the CIS oil exporters, negative spillovers from Russia contributed to around 1 per cent downward revision of their economic growth (IMF 2016).

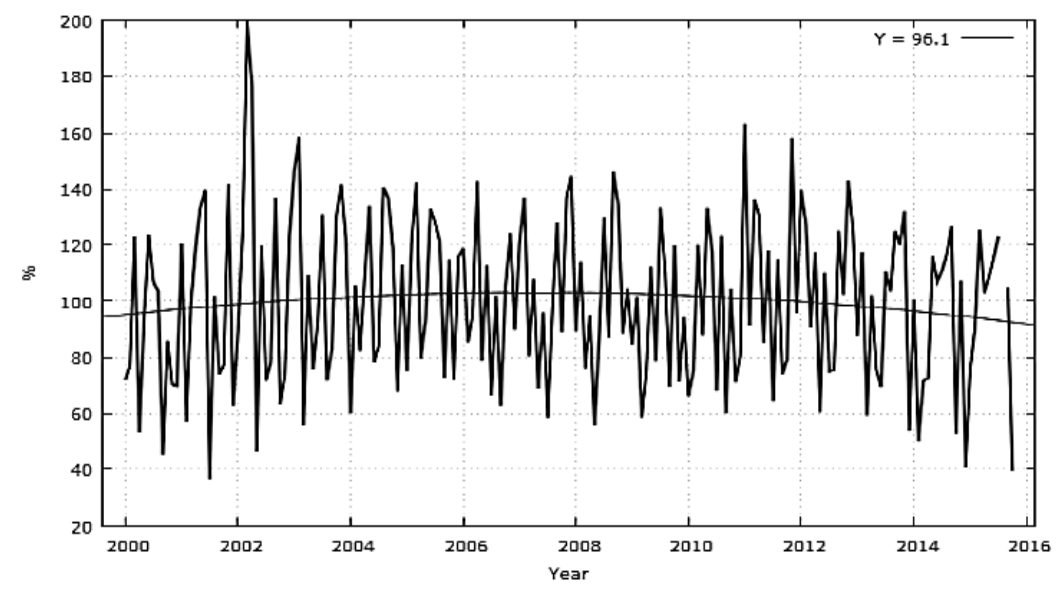

Fig. 6. The CIS countries: openness to trade in percentage, 2001-2016

Source: Authors' calculation.

The foreign trade pattern of the CIS countries is also diverse. Openness promotes a more efficient allocation of resources through comparative advantage. The average trade openness (percentage of Export + Import over GDP) amongst the CIS on average remained 96.1 per cent in 2014 (Figure 6). The World Bank (2016b) reports that some of the CIS countries are 'more open', while some of them are relatively low. For example, on average, trade openness to Belarus is 131.8, Moldova 129.1, Turkmenistan 123.9, Kyrgyzstan 112.6, Tajikistan 108.2, Ukraine 104.5, Azerbaijan 88.5, Kazakhstan 85.5, Georgia 79.5, Armenia 69.6, Uzbekistan 62.3, and Russia 56.3. We must mention that trade openness figures amongst several CIS countries are above 100 per cent mainly because these figures are from small countries with very high import levels, which are not thoroughly consumed inside the country, under the risk of double accountancy. Figure 6 indicates that in 2016 the openness to trade dramatically decreased by 71.4 per 
cent due to the ongoing financial crisis of Russia (Dorning and Katz 2016), something that reveals the CIS countries' dependence on Russian economic performance.

Table 2

Overview of the Preferential Trade Agreement in CIS area

\begin{tabular}{|c|c|c|c|c|c|c|c|c|c|c|c|c|}
\hline & ARM & AZE & GEO & KRG & MOL & TAJ & UZB & BEL & KAZ & RUS & TKM & UKR \\
\hline ARM & & $\mathrm{NO}$ & $\begin{array}{l}\text { 95-cur: } \\
\text { FTA (bl) }\end{array}$ & \begin{tabular}{|c|}
$94-11:$ \\
FTA \\
(bl)* \\
$11-$ \\
cur:FTA \\
CIS*
\end{tabular} & $\begin{array}{c}\text { 93-11: } \\
\text { FTA } \\
\text { (bl)* } \\
\text { 11-cur: } \\
\text { FTA } \\
\text { CIS* }\end{array}$ & $\begin{array}{c}\text { 11:cur: } \\
\text { FTA } \\
\text { CIS* }\end{array}$ & NO & $\begin{array}{c}\text { 00-11: } \\
\text { FTA (bl)* } \\
\text { 11-cur: } \\
\text { FTA CIS* }\end{array}$ & $\begin{array}{c}01-11: \\
\text { FTA }(\mathrm{bl})^{*} \\
11 \text {-cur: } \\
\text { FTA CIS* }\end{array}$ & $\begin{array}{c}\text { 01-11: FTA } \\
\text { (bl) } \\
\text { 11-cur:FTA } \\
\text { CIS* }\end{array}$ & $\begin{array}{c}04-11 \\
\text { FTA } \\
\text { (bl)* } \\
\text { 11-cur: } \\
\text { FTA } \\
\text { CIS* }\end{array}$ & $\begin{array}{c}96-11: \\
\text { FTA } \\
\text { (bl) } \\
\text { 11-cur: } \\
\text { FTA } \\
\text { CIS* }\end{array}$ \\
\hline AZE & $\mathrm{NO}$ & & $\begin{array}{l}\text { 96-cur: } \\
\text { FTA (bl) }\end{array}$ & NO & NO & NO & NO & NO & NO & $\begin{array}{c}\text { 93-cur FTA } \\
\text { (bl)* }\end{array}$ & NO & $\begin{array}{c}\text { 96- cur: } \\
\text { FTA } \\
\text { (bl) }\end{array}$ \\
\hline GEO & $\begin{array}{c}\text { 95-cur: } \\
\text { FTA (bl) }\end{array}$ & $\begin{array}{c}\text { 96-cur: } \\
\text { FTA } \\
\text { (bl) }\end{array}$ & & $\mathrm{NO}$ & NO & NO & NO & NO & $\begin{array}{l}\text { 97-cur: } \\
\text { FTA(bl) }\end{array}$ & $\begin{array}{l}\text { 94-cur: } \\
\text { FTA(bl) }\end{array}$ & $\begin{array}{l}\text { 96-cur: } \\
\text { FTA(bl) }\end{array}$ & $\begin{array}{c}\text { 95-cur: } \\
\text { FTA(bl } \\
\text { ) }\end{array}$ \\
\hline KRG & $\begin{array}{c}95-11: \\
\text { FTA } \\
\text { (bl)* } \\
\text { 11-cur: } \\
\text { FTA } \\
\text { CIS* } \\
\text { 15-cur: } \\
\text { EEU }\end{array}$ & $\mathrm{NO}$ & NO & & $\begin{array}{l}\text { 95-11: } \\
\text { FTA } \\
(\mathrm{bl})^{*} \\
11 \text {-cur: } \\
\text { FTA } \\
\text { CIS* }\end{array}$ & $\begin{array}{c}\text { 99-11: } \\
\text { FTA } \\
(\mathrm{bl})^{*} \\
\text { 11-cur: } \\
\text { FTA } \\
\text { CIS* }\end{array}$ & $\begin{array}{c}\text { 96-cur: } \\
\text { FTA(bl } \\
)^{*}\end{array}$ & $\begin{array}{c}\text { 99-11: } \\
\text { FTA (bl)* } \\
\text { 11-cur: } \\
\text { FTA CIS* } \\
\text { 15-cur: } \\
\text { EEU }\end{array}$ & $\begin{array}{c}\text { 95-11: } \\
\text { FTA (bl)* } \\
\text { 11-cur: } \\
\text { FTA CIS* } \\
\text { 15-cur: } \\
\text { EEU }\end{array}$ & $\begin{array}{c}\text { 92-11: FTA } \\
\text { (bl)* } \\
\text { 11-cur: FTA } \\
\text { CIS* } \\
\text { 15-cur: } \\
\text { EEU }\end{array}$ & NO & $\begin{array}{c}\text { 95-11: } \\
\text { FTA } \\
\text { (bl) } \\
\text { 11-cur: } \\
\text { FTA } \\
\text { CIS* }\end{array}$ \\
\hline MOL & $\begin{array}{c}\text { 93-11: } \\
\text { FTA (bl) } \\
\text { 11-cur: } \\
\text { FTA } \\
\text { CIS* }\end{array}$ & NO & NO & $\begin{array}{c}\text { 93-11: } \\
\text { FTA (bl) } \\
\text { 11-cur: } \\
\text { FTA } \\
\text { CIS* }\end{array}$ & & $\begin{array}{c}\text { 11-cur: } \\
\text { FTA } \\
\text { CIS* }\end{array}$ & NO & \begin{tabular}{|c|} 
93-11: \\
FTA (bl) \\
11-cur: \\
FTA CIS* \\
15-cur: \\
EEU \\
\end{tabular} & $\begin{array}{c}\text { 11-cur: } \\
\text { FTA CIS* } \\
\text { 15-cur: } \\
\text { EEU }\end{array}$ & \begin{tabular}{|c|} 
93-11: FTA \\
(bl)* \\
11-cur: FTA \\
CIS* \\
15-cur: \\
EEU \\
\end{tabular} & NO & $\begin{array}{c}\text { 11-cur: } \\
\text { FTA } \\
\text { CIS* }\end{array}$ \\
\hline TAJ & $\begin{array}{c}\text { 11-cur: } \\
\text { FTA } \\
\text { CIS* }\end{array}$ & NO & $\mathrm{NO}$ & $\begin{array}{c}\text { 99-11: } \\
\text { FTA } \\
\text { (bl)* } \\
\text { 11-cur: } \\
\text { FTA } \\
\text { CIS* }\end{array}$ & $\begin{array}{c}\text { 11-cur: } \\
\text { FTA } \\
\text { CIS* }\end{array}$ & & NO & $\begin{array}{c}\text { 98-11: } \\
\text { FTA (bl) } \\
\text { 11-cur: } \\
\text { FTA CIS* }\end{array}$ & $\begin{array}{c}95-11: \\
\text { FTA (bl)* } \\
11 \text {-cur: } \\
\text { FTA CIS* }\end{array}$ & $\begin{array}{c}\text { 92-11: FTA } \\
\text { (bl)* } \\
\text { 11-cur: FTA } \\
\text { CIS* }\end{array}$ & NO & $\begin{array}{c}\text { 01-11: } \\
\text { FTA } \\
\text { (bl) } \\
\text { 11-cur: } \\
\text { FTA } \\
\text { CIS* }\end{array}$ \\
\hline UZB & NO & NO & NO & $\begin{array}{c}\text { 96-cur: } \\
\text { FTA } \\
\text { CIS* }\end{array}$ & NO & $\mathrm{NO}$ & & NO & NO & $\begin{array}{l}\text { 99-cur: } \\
\text { FTA(bl)* }\end{array}$ & NO & $\mathrm{NO}$ \\
\hline BEL & $\begin{array}{c}00-11: \\
\text { FTA } \\
\text { (bl)* } \\
\text { 11-cur: } \\
\text { FTA } \\
\text { CIS* } \\
\text { 15-cur: } \\
\text { EEU }\end{array}$ & NO & NO & $\begin{array}{c}\text { 99-11: } \\
\text { FTA (bl) } \\
\text { 11-cur: } \\
\text { FTA } \\
\text { CIS* } \\
\text { 15-cur: } \\
\text { EEU }\end{array}$ & $\begin{array}{c}\text { 93-11: } \\
\text { FTA (bl) } \\
\text { 11-cur: } \\
\text { FTA } \\
\text { CIS* } \\
\text { 15-cur: } \\
\text { EEU }\end{array}$ & $\begin{array}{c}98-11: \\
\text { FTA } \\
\text { (bl) } \\
\text { 11-cur: } \\
\text { FTA } \\
\text { CIS* }\end{array}$ & NO & & $\begin{array}{c}\text { 97-10: } \\
\text { FTA (bl) } \\
\text { 10-cur: } \\
\text { CU } \\
\text { 11-cur: } \\
\text { FTA CIS* } \\
\text { 12-cur: } \\
\text { CES } \\
\text { 15-cur: } \\
\text { EEU }\end{array}$ & $\begin{array}{c}\text { 92-10: FTA } \\
\text { (bl)* } \\
\text { 10-cur: CU } \\
\text { 11-cur: FTA } \\
\text { CIS* } \\
\text { 12-curr: } \\
\text { CES } \\
\text { 15-cur: } \\
\text { EEU }\end{array}$ & NO & $\begin{array}{c}92-11: \\
\text { FTA } \\
\text { (bl)* } \\
11 \text {-cur: } \\
\text { FTA } \\
\text { CIS* }\end{array}$ \\
\hline $\mathrm{KAZ}$ & $\begin{array}{c}\text { 01-11: } \\
\text { FTA (bl) } \\
\text { 11-cur: } \\
\text { FTA } \\
\text { CIS* } \\
\text { 15-cur: } \\
\text { EEU }\end{array}$ & NO & $\begin{array}{c}\text { 97-cur: } \\
\text { FTA } \\
\text { (bl)* }\end{array}$ & $\begin{array}{c}\text { 95-11: } \\
\text { FTA (bl) } \\
\text { 11-cur: } \\
\text { FTA } \\
\text { CIS* } \\
\text { 15-cur: } \\
\text { EEU }\end{array}$ & $\begin{array}{l}\text { 11-cur: } \\
\text { FTA } \\
\text { CIS* }\end{array}$ & $\begin{array}{c}\text { 95-11: } \\
\text { FTA } \\
(\mathrm{bl})^{*} \\
\text { 11-cur: } \\
\text { FTA } \\
\text { CIS* }\end{array}$ & $\mathrm{NO}$ & \begin{tabular}{|c|} 
97-10: \\
FTA (bl) \\
10-cur: \\
CU \\
11-cur: \\
FTA CIS* \\
12-cur: \\
CES \\
15-cur: \\
EEU
\end{tabular} & & $\begin{array}{c}\text { 92-10: FTA } \\
\text { (bl)* } \\
\text { 10-cur: CU } \\
\text { 11-cur: FTA } \\
\text { CIS* } \\
\text { 12-cur: CES } \\
\text { 15-cur: } \\
\text { EEU }\end{array}$ & $\mathrm{NO}$ & $\begin{array}{c}\text { 94-11: } \\
\text { FTA } \\
\text { (bl) } \\
11 \text {-cur: } \\
\text { FTA } \\
\text { CIS* }\end{array}$ \\
\hline
\end{tabular}




\begin{tabular}{|c|c|c|c|c|c|c|c|c|c|c|c|c|}
\hline \multicolumn{13}{|c|}{ Table 2 continued } \\
\hline & ARM & AZE & GEO & KRG & MOL & TAJ & UZB & BEL & KAZ & RUS & TKM & UKR \\
\hline RUS & $\begin{array}{c}04-11: \\
\text { FTA } \\
\text { (bl)* } \\
11 \text {-cur: } \\
\text { FTA } \\
\text { CIS* } \\
\text { 15-cur: } \\
\text { EEU }\end{array}$ & $\begin{array}{l}\text { 93-cur: } \\
\text { FTA } \\
(\mathrm{bl})^{*}\end{array}$ & $\begin{array}{l}\text { 94-cur: } \\
\text { FTA } \\
\text { (bl)* }\end{array}$ & $\begin{array}{c}\text { 92-11: } \\
\text { FTA (bl) } \\
\text { 11-cur: } \\
\text { FTA } \\
\text { CIS* } \\
\text { 15-cur: } \\
\text { EEU }\end{array}$ & $\begin{array}{c}\text { 93-11: } \\
\text { FTA } \\
\text { (bl)* } \\
\text { 11-cur: } \\
\text { FTA } \\
\text { CIS* }\end{array}$ & $\begin{array}{c}\text { 92-11: } \\
\text { FTA } \\
\text { (bl)* } \\
\text { 11-cur: } \\
\text { FTA } \\
\text { CIS* }\end{array}$ & $\begin{array}{l}\text { 92-cur: } \\
\text { FTA } \\
\text { (bl)* }\end{array}$ & $\begin{array}{c}\text { 92-10: } \\
\text { FTA (bl)* } \\
10 \text {-cur: } \\
\text { CU } \\
11 \text {-cur: } \\
\text { FTA CIS* } \\
\text { 12-curr: } \\
\text { CES } \\
\text { 15-cur: } \\
\text { EEU }\end{array}$ & $\begin{array}{c}\text { 92-10: } \\
\text { FTA (bl)* } \\
\text { 10-cur: } \\
\text { CU } \\
\text { 11-cur: } \\
\text { FTA CIS* } \\
\text { 12-cur: } \\
\text { CES } \\
\text { 15-cur: } \\
\text { EEU }\end{array}$ & & $\begin{array}{l}\text { 92-cur: } \\
\text { FTA } \\
(\mathrm{bl})^{*}\end{array}$ & $\begin{array}{l}\text { 93-11: } \\
\text { FTA } \\
\text { (bl)* } \\
11 \text {-cur: } \\
\text { FTA } \\
\text { CIS* }\end{array}$ \\
\hline TKM & $\begin{array}{l}\text { 96-curr: } \\
\text { FTA (bl) }\end{array}$ & NO & $\begin{array}{l}\text { 96-curr: } \\
\text { FTA (bl) }\end{array}$ & NO & NO & NO & NO & NO & NO & $\begin{array}{l}\text { 92-curr: } \\
\text { FTA (bl)* }\end{array}$ & & $\begin{array}{c}95 \text {-curr: } \\
\text { FTA } \\
\text { (bl) }\end{array}$ \\
\hline UKR & $\begin{array}{c}\text { 96-11: } \\
\text { FTA (bl) } \\
\text { 11-cur: } \\
\text { FTA } \\
\text { CIS* }\end{array}$ & $\begin{array}{c}\text { 96-cur: } \\
\text { FTA } \\
\text { (bl) }\end{array}$ & $\begin{array}{l}\text { 95-cur: } \\
\text { FTA (bl) }\end{array}$ & $\begin{array}{c}\text { 95-11: } \\
\text { FTA (bl) } \\
\text { 11-cur: } \\
\text { FTA } \\
\text { CIS* }\end{array}$ & $\begin{array}{l}\text { 11-cur: } \\
\text { FTA } \\
\text { CIS* }\end{array}$ & $\begin{array}{c}01-11: \\
\text { FTA } \\
\text { (bl) } \\
\text { 11-cur: } \\
\text { FTA } \\
\text { CIS* }\end{array}$ & NO & $\begin{array}{c}\text { 92-11: } \\
\text { FTA (bl)* } \\
\text { 11-cur: } \\
\text { FTA CIS* }\end{array}$ & $\begin{array}{c}\text { 94-11: } \\
\text { FTA (bl) } \\
\text { 11-cur: } \\
\text { FTA CIS* }\end{array}$ & $\begin{array}{c}\text { 93-11: FTA } \\
\text { (bl)* } \\
\text { 11-cur: FTA } \\
\text { CIS* }\end{array}$ & $\begin{array}{c}\text { 95-cur: } \\
\text { FTA (bl) }\end{array}$ & \\
\hline
\end{tabular}

\begin{tabular}{|c|c|c|}
\hline In force & Signed, but inactive & No agreement \\
\hline
\end{tabular}

Note: (bl) - bilateral agreement; 95 - year of the signing the protocol on the complete abolition of exemptions from the free trade; *PTA with exemptions; CU - Customs union, EEU - Eurasian Economic Union, CES - Common economic space; cur - currently.

Source: Listing of bilateral international agreements of the Russian Federation - Ministry of Economic Development of the Russian Federation, World Bank Global PTA Database, WTO PTA Database, UNESCAP PTA Database, CIASSTAT Database.

The objective of creating a deeper trade link amongst post-Soviet States, namely the objective of favouring commercial integration, requires a certain degree of political integration.

The first attempt to create a multilateral FTA in the CIS area was made in September 1994 (the CIS Agreement from 15.04.1994 'On the establishment of a free trade area'), which included ten CIS countries ${ }^{15}$ and was aimed at the future establishment of an economic union. The agreement was expected to come into force after the signing parties agree on the list of exemptions from it. However, if we look at the realization of these agreements, we will find that most member countries did not implement measures to make the FTA effective ${ }^{16}$ (Kulik and Spartak 2013). Hence, the multilateral PTAs ${ }^{17}$ (Preferential trade agreements) did not exist in the CIS area until the end of 2012. Thus, the CIS countries attempted to create a multilateral PTA in a bilateral regime, concluding agreements in a relatively short time, followed by subsequent approval of the list of reciprocal exemptions and simultaneous agreements on terms of their elimination. Summary table including information on PTAs effective in 2016 in the CIS area is presented in Table 2.

Additionally, other integration processes were developing. In January 2014, Russia, Kazakhstan and Belarus signed the agreement for the creation of the Eurasian Economic Union (EEU), which came into force in 2015. The main aim of this union is creation of a common market for labour and capital. However, according to the UN reports, despite having signed an agreement, the CIS countries' trade policy is far from being 
common. The number of non-coincident import tariff rates is very high, around 50 per cent. The reason is partly the lack of a strong supra national institution to control national trade policies. Moreover, there are several agreements within the CIS Economic Union that remain dysfunctional due to governance and institutional setbacks in the CIS region (Gurova and Efremova 2012). Grinsberg and Mertenz (2005) concluded that over 1,000 official trade agreements were signed, but only about 10 per cent are effective.

Clearly, Russia is a dominant power in this project in the EEU, and its political interests may outweigh economic ones. Four potential EEU members (Belarus, Kazakhstan, Armenia and Kyrgyz Republic) have been forcefully pushed into the agreement firstly because Russia is the most accessible market for their exports and migration, and a source of cheap natural resources.

A closer regional integration among the CIS countries could complement the integration process with the world economy. Improvements of institutional bases of the organization would be the best guarantee of development. Because of poor control over the implementation of its decisions, along with the unwillingness of a number of them for further integration, the role of the Commonwealth in promoting growth and stability in the region has not reached its full potential.

\section{Methodology}

In this section we will address two important issues. Firstly, to what extent do free trade agreements, institutional and geographical factors favour the trade flows amongst the CIS countries? Secondly, whether the Russian economy exerts a strong influence on the CIS countries' bilateral flows or not.

The gravity equation provides a general empirical framework suited to the examination of these issues. This model allows us to identify the impact on bilateral trade of variables such as infrastructure, landlockedness, institutions, and free trade agreements, once all other structural determinants of trade, mainly GDP, contiguity and Russian economic development, are controlled for.

We follow the basic model suggested by Anderson and van Wincoop (2003). The selection of the best model specification has been made using the following expression:

$$
\begin{gathered}
\text { In }\left(X_{t i}\right)=\beta_{0}+\beta_{1} \text { GDP }_{t-1, i}+\beta_{2} \text { Landlocked }_{t i}+\beta_{3} \text { Contiquity }_{t i}+\quad \text { Eq. } 1 \\
\beta_{4} \text { RusCrrAcC }_{t i}+\beta_{5} \text { RussIncm }_{t i}+\beta_{6} \text { GovEff }_{t i}+\beta_{8} \text { RegM }_{t i}+ \\
\beta_{9} \text { PSAV }_{t i}+\beta_{9} \text { VoiceAcc }_{t i}+\beta_{9} \text { CISFTA }_{t i}+\omega_{t i} \\
\omega_{t i}=\mu_{i}+v_{t i}, t=1, \ldots, T ; i=1, \ldots, N
\end{gathered}
$$

We applied a fixed effects (FE) model, which assumes constant but not equal individual country effects, which leads to a fixed effect model. The second method is a random effect (RE) method, and the assumption is a situation where the country effects are not constant, but are treated such as disturbances.

We estimated our model using a panel data set of bilateral export flows between Russia and each of the eleven CIS countries. The time span for the analysis is 17 years from 1997 to 2014, due to the limited data available. We test the importance of the trade regime (Free Trade Association Regime between the two countries partners). Additionally, we check the effect of the relevance of Russian economic policy and performance on bilateral commerce figures, the reason why bilateral Russia-other CIS partners' flows 
are used. We will test the link between each country's institutions ${ }^{18}$ quality and trade flows. In addition to these variables, we include a rich set of control variables, such as GDP, landlockedness and the effect of contiguity. However, we do not use distance, as it does not show statistical significance because Moscow, which is the main trading centre-partner for most CIS countries, is very far from the frontiers of all CIS countries. The definition, description and expected sign of each variable are indicated in Table 3.

Table 3

Definition of the variables

\begin{tabular}{|c|c|c|c|c|}
\hline Variables & Description & Formula & $\begin{array}{c}\text { Ex- } \\
\text { pected } \\
\text { sign }\end{array}$ & Source \\
\hline $\operatorname{In} X_{i j t}$ & $\begin{array}{l}\text { Log of export of country } i \text { to country } j, \\
\text { f.o.b. value in million USD }\end{array}$ & & & IMF-DOT \\
\hline$\overline{\mathrm{InGDP}}_{i t}$ & $\begin{array}{l}\text { Log of GDP of country } i \text {, in current USD, } \\
\text { in million USD }\end{array}$ & & + & $\begin{array}{l}\text { WDI } \\
\text { (worldwide } \\
\text { global indi- } \\
\text { cators) }\end{array}$ \\
\hline $\operatorname{InGDP}_{i j t}$ & $\begin{array}{l}\text { Log of GDP of country } j \text {, in current USD, } \\
\text { in million USD where } i \text { exporting }, j \text { im- } \\
\text { porting countries }\end{array}$ & & + & WDI \\
\hline Landlocked & Dummy for landlocked & $\begin{array}{l}1 \text { if country } i \\
\text { and } j \text { are land- } \\
\text { locked and } 0 \\
\text { otherwise }\end{array}$ & - & CEPII \\
\hline Contig $_{i j}$ & $\begin{array}{l}\text { Dummy contiguity } i j \text { for having a common } \\
\text { border between the countries }\end{array}$ & $\begin{array}{l}1 \text { if countries } i \\
\text { and } j \text { are con- } \\
\text { tiguous; } \\
0 \text { otherwise }\end{array}$ & + & CEPII \\
\hline $\begin{array}{l}\text { RUS_CURR } \\
\text { ACC (as } \\
\text { percentage } \\
\text { of CIS trade) }\end{array}$ & $\begin{array}{l}\text { An indicator of the national savings that are } \\
\text { available for investment abroad - expressed } \\
\text { as a ratio of the combined CIS trade }\end{array}$ & & + & $\begin{array}{l}\text { WB } \\
\text { IMF-DOT }\end{array}$ \\
\hline $\begin{array}{l}\text { RUS } \\
\text { INCOME } \\
\text { (\% over CIS } \\
\text { trade) }\end{array}$ & & & + & $\begin{array}{l}\text { WB and } \\
\text { IMF-DOT }\end{array}$ \\
\hline $\begin{array}{l}\text { Government } \\
\text { Effective- } \\
\text { ness }\end{array}$ & $\begin{array}{l}\text { Measures the perceptions of public ser- } \\
\text { vices' quality, civil services' quality, quali- } \\
\text { ty of formulation and implementation of } \\
\text { polices and credibility of government's } \\
\text { commitment to follow the policies for } \\
\text { country } i \text { and } j\end{array}$ & $\begin{array}{l}\operatorname{Goveff}_{i t}= \\
\left(\operatorname{cor}_{j t}+\operatorname{law}_{j t}+\right. \\
\operatorname{reg}_{j t}+\operatorname{acc}_{j t}+ \\
\left.\operatorname{polstab}_{j t}\right)\end{array}$ & $+1-$ & WBI- WGI \\
\hline $\begin{array}{l}\text { Governance } \\
\text { it }\end{array}$ & $\begin{array}{l}\text { Simple average of governance score for } \\
\text { country i based on: control of corruption, } \\
\text { rule of law, regulatory quality, voice and } \\
\text { accountability, government effectiveness, } \\
\text { political stability and absence of violence }\end{array}$ & $\begin{array}{l}\text { Governance } i t= \\
\left(\operatorname{cor}_{i t}+\operatorname{law}_{i t}+\right. \\
\operatorname{reg}_{i t}+\operatorname{acc}_{i t}+ \\
\left.\operatorname{gov}_{i t}+\text { polstab }_{i t}\right)\end{array}$ & $+1-$ & $\begin{array}{l}\text { Own calcula- } \\
\text { tions based } \\
\text { on WBI- } \\
\text { WGI }\end{array}$ \\
\hline $\begin{array}{l}\text { Governance } \\
\text { jt }\end{array}$ & $\begin{array}{l}\text { Simple average of governance score for } \\
\text { country j based on: control of corruption, } \\
\text { rule of law, regulatory quality, voice and } \\
\text { accountability, government effectiveness, }\end{array}$ & $\begin{array}{l}\text { Governance }_{i t}= \\
\left(\operatorname{cor}_{j t}+\operatorname{law}_{j t}+\right. \\
\operatorname{reg}_{j t}+\operatorname{acc}_{j t}+ \\
\left.\operatorname{gov}_{j t}+\text { polstab }_{j t}\right)\end{array}$ & $+1-$ & $\begin{array}{l}\text { Own calcula- } \\
\text { tions based } \\
\text { on WBI- } \\
\text { WGI }\end{array}$ \\
\hline
\end{tabular}


Table 3 continued

\begin{tabular}{|c|c|c|c|c|}
\hline $\begin{array}{l}\text { Regulatory } \\
\text { Quality }\end{array}$ & $\begin{array}{l}\text { Measures the perceptions of governmental } \\
\text { capabilities to draw and implement policies } \\
\text { for development of private sector for coun- } \\
\text { try } i \text { and } j\end{array}$ & $\begin{array}{l}\operatorname{Reg}_{i t}=\left(\operatorname{cor}_{j t}+\right. \\
\operatorname{law}_{j t}+\operatorname{gov}_{\mathrm{jt}}+ \\
\left.\operatorname{acc}_{j t}+\operatorname{polstab}_{j t}\right)\end{array}$ & $+/-$ & WBI- WGI \\
\hline $\begin{array}{l}\text { Political } \\
\text { Stability and } \\
\text { Absence of } \\
\text { Violence/ } \\
\text { Terrorism }\end{array}$ & $\begin{array}{l}\text { Measures the perceptions of the likelihood } \\
\text { of government overthrow, political violence } \\
\text { and terrorism for country } i \text { and } j\end{array}$ & $\begin{array}{l}\operatorname{Polstab}_{i t}= \\
\left(\operatorname{cor}_{j t}+\operatorname{law}_{j t}+\right. \\
\operatorname{reg}_{j t}+\operatorname{gov}_{\mathrm{jt}}+ \\
\left.\operatorname{acc}_{j t}\right)\end{array}$ & $+1-$ & WBI- WGI \\
\hline Rule of Law & $\begin{array}{l}\text { Measures the perceptions of the contract } \\
\text { reinforcement quality, respect for property } \\
\text { rights, the quality of police and the courts, } \\
\text { likelihood of crime and violence for coun- } \\
\text { try } i \& j\end{array}$ & $\begin{array}{l}\operatorname{Law}_{i t}=\left(\operatorname{cor}_{j t}+\right. \\
\operatorname{reg}_{j t}+\operatorname{gov}_{\mathrm{jt}}+ \\
\operatorname{acc}_{j t}+ \\
\left.\operatorname{polstab}_{j t}\right)\end{array}$ & $+1-$ & WBI- WGI \\
\hline $\begin{array}{l}\text { Voice and } \\
\text { Accountabil- } \\
\text { ity }\end{array}$ & $\begin{array}{l}\text { Measures perceptions of the degree to } \\
\text { which citizens can participate in govern- } \\
\text { ment selection; freedom of expression, } \\
\text { freedom of association and media for coun- } \\
\text { try } i \text { and } j\end{array}$ & $\begin{array}{l}\operatorname{Acc}_{i t}=\left(\operatorname{cor}_{j t}+\right. \\
\operatorname{law}_{j t}+\operatorname{reg}_{j t}+ \\
\operatorname{gov}_{\mathrm{jt}}+ \\
\left.\operatorname{polstab}_{j t}\right)\end{array}$ & $+1-$ & WBI- WGI \\
\hline FTAij & Dummy for an FTA between country $i$ and $j$ & $\begin{array}{l}1 \text { if countries } i \\
\text { and } j \text { have and } \\
\text { FTA; } 0 \text { other- } \\
\text { wise }\end{array}$ & + & $\begin{array}{l}\text { WTO and } \\
\text { CISSTAT } \\
\text { RTA data- } \\
\text { base }\end{array}$ \\
\hline
\end{tabular}

Note: The institutional variables are taken from the World Bank's database of Worldwide Governance Indicators and calculated separately for exporting and importing country as a simple average of six indicators. These six indicators represent quality of governance in the three main areas: Selection, monitoring and replacement process of governments.

\section{Main Results}

The results of the estimation are presented in Table 4.

Our results suggest that Russian economic performance is positively related to bilateral trade flows, so we can state that Russian economy's health (proxied with the inclusion of Russian Income and Russian Current Account variable) positively affects bilateral trade flows. It also should be noted that trade between the CIS countries is favoured by the existence of an FTA bilateral agreement, confirming the hypotheses put forward above. The results in columns (1) and (4) in Table 4 reveal that FTA has positive and statistically significant effects on trade flows.

Regarding signs, estimated coefficients across different estimators show the expected relationship with the dependent variable.

Trade, as expected, is positively associated with exporter and importer GDPs. However, the coefficients estimated for the exporting and importing countries do slightly differ from each other. Supply determinants are more significant than demand ones: coefficients for the RE model range from 0.154 to 0.194 and from 0.030 to 0.032 by FE models for the exporting country. For the importing country, our coefficient ranges only from 0.098 to 0.114 (RE) and from 0.001 to 0.0008 (FE).

In contrast, landlockedness is negatively correlated with trade. Both our RE model procedures show negative results of -2.115 and -0.486 for that variable, while FE mod- 
els show similar negative results. Although in many gravity papers the common border is found to have a positive correlation with trade in our model it does not register a statistically significant result.

As we mentioned in Section 5, we do not use distance, as it does not show statistical significance because of huge distance between the CIS countries and major industrial areas of Russia (Moscow, Ural and Siberia).

Table 4

GDP growth rate in CIS countries: Regression results

\begin{tabular}{|c|c|c|c|c|}
\hline & MODEL 1 & MODEL 2 & MODEL 1 & MODEL2 \\
\hline Variables & Random Effect & Random Effect & Fixed Effect & Fixed Effect \\
\hline CONST & $14.2940 * * *$ & $15.6558 * * *$ & $14.8113^{* * *}$ & $15.7892 * * *$ \\
\hline GDP_X_USD & $0.194833^{* * *}$ & $0.154915^{* * *}$ & $0.0326209 * * *$ & $0.0304988^{* * *}$ \\
\hline GDP_M_USD & $0.114661^{* * *}$ & $0.0986743 * * *$ & $0.001122547^{*}$ & 0.000886885 \\
\hline Landlocked_0 & $-2.11573 * * *$ & $-0.48602 * * *$ & $-2.59631 * * *$ & $-2.58965 * * *$ \\
\hline Contiguity & 0.0845933 & 0.0802030 & 0.0860580 & 0.104733 \\
\hline RUS_CURR_ACC & $0.0431802 * * *$ & $0.0263873 * * *$ & $0.207349 * * *$ & $0.199077 * * *$ \\
\hline RUS_INCOME & $0.0428229 * *$ & $0.0244380 * * *$ & $3.44454 * * *$ & $3.14826^{* * *}$ \\
\hline GOVEFF_M & - & $0.248074 * * *$ & - & 0.000799202 \\
\hline REGQ_M & - & $0.638863 * * *$ & - & -0.0249250 \\
\hline PSAV_X & - & $1.17621 * * *$ & - & $0.284640 * * *$ \\
\hline Voice_Acc_X & - & $-1.47401 * * *$ & - & $-0.601901 * * *$ \\
\hline CIS FTA_X & $1.39310 * * *$ & - & - & $1.49478^{* * *}$ \\
\hline- & - & - & $-2.30611 * * *$ & $-2.17224 * * *$ \\
\hline- & - & - & $-2.49145^{* * *}$ & $-2.34241 * * *$ \\
\hline- & - & - & $-3.04355^{* * *}$ & $-2.88818^{* * *}$ \\
\hline- & - & - & $-1.95947 * * *$ & $-1.89300 * * *$ \\
\hline- & - & - & $4.96002 * * *$ & $4.46442 * * *$ \\
\hline- & - & - & $-3.06073^{* * *}$ & $-2.84299^{* * *}$ \\
\hline- & - & - & $0.171544 *$ & $0.110577 * * *$ \\
\hline- & - & - & $-0.581723 * * *$ & $-3.0613772 * * *$ \\
\hline- & - & - & $-3.38115^{* * *}$ & $3.14419 * * *$ \\
\hline- & - & - & $-3.42003 * * *$ & $-3.16764 * * *$ \\
\hline- & - & - & $3.59030^{* * *}$ & $3.24748^{* * *}$ \\
\hline- & - & - & $2.35479 * * *$ & $2.15142 * * *$ \\
\hline No. of observations & 2512 & 2512 & 2512 & 2512 \\
\hline R-squared & 0.73 & 0.81 & 0.69 & 0.74 \\
\hline Adjusted R-squared & 0.68 & 0.79 & 0.67 & 0.70 \\
\hline
\end{tabular}

Regarding institutional variables, our estimates show that government effectiveness and regulatory quality (among importing countries) register the expected positive and 
significant sign for the RE procedure, while the absence of violence (exporting countries) reveal the expected positive result for both the FE and the RE procedures. However, the measure of the level of democracy (Voice Accountability) appears to be negatively correlated with export flows.

\section{Conclusions}

Our findings suggest that the creation of FTA has positively influenced trade flows amongst the CIS countries, mainly because FTAs allow the CIS countries to decrease the size of transit costs.

Secondly, the CIS countries can give the largest boost to their exports by improving their governance quality, especially in the areas of governmental effectiveness, regulation and absence of violence, the level of democracy. However, voice accountability does not seem to favour trade growth. Although improvement of governance quality in the CIS countries is a challenging process that could take some time, it is definitely a job worth accomplishing.

Thirdly, another factor having considerable effects on the CIS trade growth is landlockedness due to the lack of access to the sea ports (Grigoriou 2007; Kulipanova 2012) and transit systems in the CIS region (Raballand 2003). In support of Hypothesis 3, our empirical analyses suggest that geographical disadvantage negatively affects the CIS trade flows. High transport costs are certainly one of the main impediments to the reorientation of the CIS trade flows. Because overland distances are more penalizing than sea distances due to their higher costs per mile (Carrere and Grigoriou 2008), the CIS landlocked countries (particularly Central Asian countries) are dependent on sovereign transit countries for their trade. Moreover, high transportation costs amongst the CIS countries have a negative impact, not just on transportation budgets, but also on broader supply chain and financial performance.

In support of the fourth hypothesis, our study suggests that the economic policy and performance of Russia have a strong impact on trade growth in the rest CIS countries, primarily via remittances, FDI and exports. The strength and nature of the economic linkages between Russia and the CIS countries are still greater than might be expected. Thus, those experts who foresaw that a country's trade with their colonizer typically falls after 30 years of independence, or predicted that Russia influence would quickly vanish among the CIS countries after the collapse Soviet Union, were mistaken.

Furthermore, the globalization process does not seem to have exerted so far, such a strong influence on the CIS countries' intra-regional trade growth. Geographical obstacles, problems with the management of different Free Trade Agreements or certain lack of commercial complementariness have hindered trade expansion amongst the CIS countries. Therefore, we can accept the fifth hypothesis put forward in the introduction. In consequence, there should be an additional joint effort to reform regional trade agreements, apart from a progressive improvement of infrastructures to favour trade growth.

\section{NOTES}

${ }^{1}$ The Soviet Union with 15 republics ceased to exist in 1991, when the Commonwealth of Independent States (CIS) was established.

${ }^{2}$ The EEU or EAEU members are: Armenia, Belarus, Kazakhstan, Kyrgyzstan and Russia. 
${ }^{3}$ According to the geographical definition, a landlocked country is one that does not have open access to the sea (Raballand 2003).

${ }^{4}$ The positive relation between trade and growth was also found in, among others, Mckinnon (1973), Shaw (1973), Dollar (1992), Sachs and Warner (1995), Levine (1997), Edwards (1998), Frankel and Rommer (1999), Jin (2000), Wacziarg (2001), Greenaway et al. (2002), Berg and Krueger (2003), Winter (2004) and Anderson and Babula (2008).

${ }^{5}$ Vamvakidis (2002), using cross-section data for developed and developing countries over the period from 1920 to 1990 , revealed that there was no positive relationship between openness to international trade and economic growth before 1970.

${ }^{6}$ Armenia, Azerbaijan, Belarus, Kazakhstan and Ukraine.

${ }^{7}$ Estonia, Latvia and Lithuania.

${ }^{8}$ The CIS-7 countries include Armenia, Azerbaijan, Georgia, Kyrgyz Republic, Moldova, Tajikistan and Uzbekistan.

${ }^{9}$ Moers (1999), Grogan and Moers (2001) have concluded that high corruption levels reduce the volume of inward FDI

${ }^{10}$ EBRD indicates that transition countries, on average, trade between 40 and 75 per cent less than the average non-transition country.

${ }^{11}$ Obviously, distance and geographical factors, in general, can explain the level of transport costs. Bilateral distance is, for instance, at the core of the gravity approach. Tinbergen (1962) empirically demonstrated the negative correlation between bilateral distance and trade flows.

${ }^{12}$ United Nations Office of the High Representative for the Least Developed Countries, Landlocked Developing Countries and Small Island Developing States.

${ }^{13}$ This group of countries includes Armenia, Azerbaijan, Georgia, Kyrgyzstan, Moldova, Tajikistan, and Uzbekistan.

${ }^{14}$ Only Kazakhstan and Turkmenistan have access to the Caspian Sea, while Kyrgyzstan, Tajikistan and Uzbekistan are twice landlocked countries, i.e. surrounded by countries that are themselves landlocked.

${ }^{15}$ Armenia, Azerbaijan, Belarus, Georgia, Kazakhstan, Kyrgyzstan, Moldova, Russia, Tajikistan and Uzbekistan.

${ }^{16}$ In 2008, Georgia, due to Russian political intervention in the Georgian region of Abkhazia, and in 2010, Ukraine due to the Orange Revolution, decided to leave the Economic Union.

${ }^{17}$ Preferential trade agreement is a trading bloc that gives preferential access to certain products from the participating countries. This is carried out by reducing tariffs but not by abolishing them completely.

${ }^{18}$ As measured by the World Bank governance indicators.

\section{REFERENCES}

Abduvaliev, M., and Bustillo, R. 2020. Impact of Remittances on Economic Growth and Poverty Reduction amongst CIS Countries. Post-Communist Economies 32 (4): 525-546.

Abrams, R. K. 1980. International Trade Flows under Flexible Exchange Rates. Economic Review 65 (3): 3-10.

Acemoglu, D., and Robinson, J. A. 2002. Economic Backwardness in Political Perspective. NBER Working Paper 8831. National Bureau of Economic Research, Inc.

Acemoglu, D., and Robinson, J. A. 2006. Persistence of Power, Elites and Institutions. National Bureau of Economic Research (No. w12108). 
Aitken, N. D. 1973. The Effect of the EEC and EFTA on European Trade: A Temporal Cross-Section Analysis. The American Economic Review 63 (5): 881-892.

Anderson, J. E., and van Wincoop, E. 2003. Gravity with Gravitas: A Solution to the Border Puzzle. American Economic Review 93 (1): 170-192.

Anderson, L., and Babula, R. 2008. The Link between Openness and Long-Run Economic Growth. Journal of International Commerce and Economics 2: 31-50.

Andreev, A. V. 2010. Economic Integration of CIS countries: Problem and Challenges. Rossiyskiy vneshneekonomicheskiy vestnik 7: 72-83. Original in Russian (Андреев, А. В. Экономическая интеграция в рамках стран СНГ: направление и проблемы. Российский внешнеэкономический вестник 7: 72-83).

Asian Development Bank. 2010. Central Asia, Increasing Gains from Trade through Regional Cooperation in Trade Policy, Transport, and Customs Transit. Philippines, Manila.

Babetskaia-Kukharchuk, O., and Maurel, M. 2004. Russia's Accession to the WTO: What Potential for Trade Increase. Journal of Comparative Economics 32: 680-699.

Babetskii, I., Babetskaia-Kukharchuk, O. and Raizer, M. 2003. How Deep is Your Trade? Transition and International Integration in Eastern Europe and the Former Soviet Union. European Bank for Reconstruction and Development.

Baier, S. L., and Bergstrand, J. H. 2007. Do Free Trade Agreements Actually Increase Members' International Trade? Journal of International Economics 71 (1): 72-95.

Baldwin, R. E. 2003. Openness and Growth: What's the Empirical Relationship? NBER Working paper 9578, National Bureau of Economic Research, Inc.

Basargin, S. L. 2012. The New Stage of Integration. Moscow. Original in Russian (Баcapгин С. Л. Новый этап интеграции. Москва).

Beilock, R., and Boneva, P. et al. 1996. Road Conditions, Border Crossings and Freight Rates in Europe and Western Asia. Transportation Quarterly 50 (1): 79-90.

Berg, A., and Krueger, A. O. 2003. Trade, Growth, and Poverty: A Selective Survey. IMF Working Papers 03/30. URL: https://www.elibrary.imf.org/view/journals/001/2003/030/ 001.2003.issue-030-en.xml

Bergstrand, J. H. 1985. The Gravity Equation in International Trade: Some Microeconomic Foundations and Empirical Evidence. Review of Economics and Statistics 67 (3): 474-481.

Bougheas, S et al. 1999. Infrastructure, Transport Costs, and Trade. Journal of International Economics 47: 169-189.

Brada, J. C., and Mendez, J. A. 1985. Economic Integration among Developed, Developing and Centrally Planned Economies: a Comparative Analysis. Review of Economics and Statistics 67 (4): 549-556.

Brethelot, Y. 1999. Europe in a Global Economy: Challenges, Problem and Prospects. Paper presented at the international conference on globalization, Ljubljana, December 1999.

Burnside, C., and Dollar, D. 2000. Aid, Policies, and Growth. American Economic Review 90: 847-69.

Carrere, C., and Grigoriou Ch. 2008. Landlockedness, Infrastructure and Trade: New Estimates for Central Asian Countries. CERDI Working Papers 29: 5-11. DOI: https:// halshs.archivesouvertes.fr/halshs-00556941/ 
CBR - Central Bank of Russia. 2017. Bank of Russia Annual Report for 2017. URL: http://www.cbr.ru/eng/about_br/publ/god/. Accessed in April 2018.

CISSTAT - Commonwealth Independent States Committee Report. 2017. Monitoring of the state of national labor markets country Commonwealth of Independent States. 20132016. Moscow. Original in Russian (Статкомитет СНГ. Мониторинг состояния национальных ринков труда страна Содружество Независимых Государств 2013-2016. М.: Межгосударственный статистический комитет СНГ).

De Souza, L. V. 2004. A Wider Europe: Trade Relations between an Enlarged EU and the Russian Federation. CASE Studies \& Analyses No. 279.

Djankov, S., and Freund, C. 2000. Disintegration and Trade and Flows, Evidence from the Former Soviet Union. World Bank, Financial Sector Strategy and Policy Department, Policy Research Paper 2378.

Djankov, S., and Freund, C. 2002. Trade Flows in the Former Soviet Union, 1987 to 1996. Journal of Comparative Economics 30: 76-90.

Dollar, D. 1992. Outward-Oriented Developing Economies Really Do Grow More Rapidly: Evidence from 95 LDCs, 1976-85. Economic Development and Cultural Change 40 (3): 523-544.

Dorning, M., and Katz, I. 2016. The Unites States Won't Ease Sanctions to Stem Russia's Economic Crisis. Bloomberg, December 16. URL: https:/www.bloomberg.com/news/ articles/2014-12-16.

Dreger, Ch., Fidrmuc, J., Kholodilin, K., and Ulbricht, D. 2015. The Ruble between the Hammer and the Anvil: Oil Prices and Economic Sanctions. Discussion Papers 1488. Berlin: DIW Berlin, German Institute for Economic Research.

Edwards, S. 1998. Openness, Productivity and Growth: What do We Really Know? Economic Journal 108: 383-398. DOI: 10.3386/w5978. URL: https://www.jstor.org/stable/ 2565567.

Elborgh-Woytek, K. 2003. Of Openness and Distance: Trade Developments in the Commonwealth of Independent States, 1993-2002. IMF Working Paper 03/207 Washington: International Monetary Fund.

Emerson, T., Edwards, H., Gazizullin, I., Lucke, M., Jentsch, M., Nanivska, V., Shevtsov, G., and Shumylo, O. 2006. The Prospects of Deep Free Trade between the European Union and Ukraine. Brussels: Centre for European Policy Studies.

EBRD - European Bank for Reconstruction and Development. 2003. Transition Report: Integration and Regional Cooperation. London: EBRD.

Falyakhov, F. 2013. Co-ordinating Conjunction. Gazeta.tu, December 24. URL: https://www. gazeta.ru/business/2013/12/24/5818017.shtml. Original in Russian (Фаляхов Р. Сочинительный Союз. Газета.ru, 24 декабря).

Feenstra, R. C., and Hanson, G. H. 1996. Foreign Investment, Outsourcing and Relative Wages. In Feenstra, R. C., Grossman, G. M., and Irwin, D. A. (eds.), The Political Economy of Trade Policy: Papers in honor of Jagdish Bhagwati (pp. 89-127). Cambrige, MA: MIT Press.

Fidrmuc, J., and Fidrmuc, J. 2003. Disintegration and Trade. Review of International Economics 11 (5): 811-829. 
Francois, J., and Manchin, M. 2009. Economic Impact of a Potential Free Trade Agreement (FTA) between the European Union and the Commonwealth of the Independent States, CASE Network Reports No. 84. Warsaw.

Frankel, J. A. and Romer, D. 1995. Does Trade Cause Growth? The American Economic Review, June: 379-399. URL: https://eml.berkeley.edu/ dromer/papers/AER_June99.pdf.

Freinkman, L., Polyakov, E., and Revenco, C. 2004. Trade Performance and Regional Integration of the CIS Countries. World Bank working paper 38. Washington, DC: World Bank.

Galstyan, N. S. 2017. Armenia's Foreign Policy in the Public Perception. In Kakachia, K., and Markarov, A. (eds.), Values and Identity as Sources of Foreign Policy in Armenia and Georgia (pp. 233-263). Tbilisi: Universal.

Grafe, C., Raiser, M., and Sakatsume, T. 2005. The Importance of Good Neighbors: Regional Trade in Central Asia. In Auty, R. M. (ed.), Lessons not Learned: Natural Resource Rent and Social Welfare in the CCA Countries. London: Routledge Curzon.

Greenaway, D., Morgan, W., and Wright, P. 2002. Trade Liberalization and Growth in Developing Countries. Journal of Development Economics 67: 229-244.

Grogan, L., and Moers, L. 2001. Growth Empirics with Institutional Measures for Transition Countries. Economic Systems, 25 (4): 323-344. URL: https://ideas.repec.org/a/eee/ecosys/ v25y2001i4p323-344.html.

Grigoriou, C. 2007. Landlockedness, Infrastructure and Trade: New Estimates for Central Asian countries. Policy Research Working Paper. World Bank. DOI: https://halshs. archives-ouvertes.fr/halshs-00556941/.

Grinsberg, P., and Mertenz, D. 2005. The Handbook of Social Research Ethics. Washington DC: Sage. DOI: https://dx.doi.org/10.4135/9781483348971.

Grossman, G. M., and Helpman, E. 1991. Trade, Knowledge Spillovers, and Growth. NBER Working Papers 3485. DOI: http://www.nber.org/papers/w3485.pdf.

Gurova, I. P., Efremova, M. V. 2012. Intra-Branch and Interindustry Trade of the CIS Region. Evraziiskaya ekonomicheskaya integratsiya 3 (16): 30-39. Original in Russian (Гурова И. П., Ефремова М. В. Внутриотраслевая и межотраслевая торговля СНГ. Евразийская экономическая интегращия 3 (16): 30-39).

Hallak, C., and Levinsohn, J. 2004. Fooling Ourselves: Evaluating The Globalization and Growth Debate. NBER, Working Paper No. 10244. DOI: 10.3386/w10244.

Hamilton, C., and Winters, L. A. 1992. Opening up International Trade in Eastern Europe. Economic Policy 14: 77-116.

Havrylyshyn, O., and Al-Atrash, H. 1998. Opening Up and Geographic Diversification of Trade in Transition Economies. IMF, WP 98/22 DOI: 10.1007/s11079-010-9187-8

Head, K., Mayer, T., and Ries, J. 2010. The Erosion of Colonial Trade Linkages after Independence. Journal of International Economics 81 (1): 1-14.

Hoffmann, S. 2002. The Clash of Globalizations. Foreign Affairs 81 (4): 104-115.

Hogan-Brun, G. (guest ed.) 2005. Baltic Sociolinguistic Review. Special Issue of Journal of Baltic Studies 36 (3). URL: https://www.researchgate.net/publication/233183611.

IMF - International Monetary Fund. 2001. International Monetary Fund Annual Report 2001: Making the Global Economy Work. Washington, D.C: International Monetary Fund. 
IMF - International Monetary Fund. 2002. Globalization: A Framework for IMF Involvement. URL: https://www.imf.org/external/np/exr/ib/2002/031502.htm.

IMF - International Monetary Fund. 2015a. World Economic Outlook. Slower Growth in Emerging Markets, a Gradual Pickup in Advanced Economies. Washington, D.C: International Monetary Fund.

IMF - International Monetary Fund. 2015b. Russian Federation: Selected Issues. Washington, D.C: International Monetary Fund. URL: https://www.elibrary.imf.org/view/journals/ 002/2015/212/article-A003-en.xml.

IMF - International Monetary Fund. 2016. World Economic Outlook Database. URL: https://www.imf.org/external/pubs/ft/weo/2016/02/weodata/index.aspx.

IMF - International Monetary Fund. 2017. World Economic Outlook Database. October 2017. URL: https://www.imf.org/en/Publications/WEO/weo-database/2017/October.

McKinnon, R. I. 1973. Money and Capital in Economic Development. Washington D.C.: Brookings Institution.

Jenish, N. 2015. Walls and Windmills: Economic Development in Central Asia. In Denoon, D. (ed.), China, the United States and the Future of Central Asia (pp. 20-74). New York: New York University Press.

Jin, J. C. 2000. Openness and Growth: An Interpretation of Empirical Evidence from East Asian Countries. The Journal of International Trade \& Economic Development 9 (1): 5-17.

Kitade, D. 2019. Central Asia Undergoing a Remarkable Transformation: Belt and Road Initiative and Intra Regional Cooperation. Mitsui and Co. Global Strategic Studies Institute Monthly Report, August 2019. URL: https://www.mitsui.com/mgssi/en/report/ detail/_icsFiles/afieldfile/2019/08/27/1908e_kitade_e_1.pdf.

Krapohl, S., and Vasileva-Dienes, A. 2019. The Region that isn't: China, Russia and the Failure of Regional Integration in Central Asia. Asia Europe Journal 1.05: 1-20.

Kulik, S. A., Spartak, A. N., and Yurgens, I. Yu. 2013. Economic Interests and Problems of Russia in the CIS Countries. Moscow: Ekon-Inform. Original in Russian (Кулик, C. А., Спартак, А. Н., Юргенс И. Ю. Экономические интересы и проблемы России в странах СНГ. Москва: Экон-Информ).

Kulipanova, E. 2012. International Transport in Central Asia: Understanding the Patterns of (non-) Cooperation. Working papers no. 2. University of Central Asia.

Kurmanalieva, E., and Vinokurov, E. 2011. Holding Together or Falling Apart: Results of Gravity Equation of the CIS Trade. Eurasian Development Bank.

Lee, J. W., and Swagel, P. 1997. Trade Barriers and Trade Flows across Countries and Industries. Review of Economics and Statistics 79: 372-382. URL: https://koreauniv. pure.elsevier.com/en/publications.

Levine, R. 1997. Financial Development and Economic Growth: Views and Agenda. Journal of Economic Literature 35 (2): 688-726.

Limao, N., and Venables, A. J. 2001. Infrastructure, Geographical Disadvantage and Transit Costs. World Bank Economic Review 15: 451-479.

Maliszewska, M. 2008. Economic Feasibility, General Economic Impact and Implications of a Free Trade Agreement between the European Union and Georgia. CASE Network Report No. 79/2008. 
Mattli, W. 1999. The Logic of Regional Integration: Europe and Beyond. Cambridge: Cambridge University Press.

Mendoza, R. U. 2010. Trade and Growth in the Post-Crisis World. World Economics 11 (4): 29-36. URL https://papers.ssrn.com/sol3/papers.cfm?abstract_id=1741834.

Moers, L. 1999. How Important are Institutions for Growth in Transition Countries? Tinbergen Institute Discussion Papers 99-004/2, Tinbergen Institute.

Mrak, M. 2000. Globalization: Trends, Challenges and Opportunities got Countries of Transition. Vienna: UNIDO.

Myant, M., and Drahokoupil, J. 2008. International Integration and the Structure of Exports in Central Asian Republics. Eurasian Geography and Economics 49 (5): 604-622.

Nixey, J. A. 2012. The Long Goodbye: Waning Russian Influence in the South Caucasus and Central Asia. Russia and Eurasia Programme, REP RSP BP 2012/03.

North, D. C. 1981. Structure and Change in Economic History. New York: W.W. Norton \& Co. DOI: https://doi.org/10.1177/003232928201100416

OECD/DAC. - The Organization for Economic Co-operation and Development's Development Assistance Committee. 2015. URL: www.OECD.org/statistics/.

Panagariya, A. 2004. Miracles and Debacles: In Defence of Trade Openness. World Economy 27 (8). URL: http://dx.doi.org/10.1111/j.1467-9701.2004.00650.x.

Raballand, G. 2003. Determinants of the Negative Impact of Being Landlocked on Trade: An Empirical Investigation through the Central Asian Case. Comparative Economic Studies 45: 520-536.

Raballand, G., Kunth, A., and Auty, R. 2005. Central Asia's Transport Cost Burden and its impact on Trade. Economic Systems 29: 6-31.

Radelet, S., and Sachs, J. 1998. The East Asian Financial Crisis: Diagnosis, Remedies, Prospects. Harvard Institute for International Development.

Robson, J. M. 2006. Estimating Russia's Impact on the Economic Performance of the Commonwealth of Independent States since 1991 - The Cases of the Kyrgyz Republic, Tajikistan, Armenia, Georgia and Ukraine. IMF Working Discussion Paper.

Rodriguez, F., and Rodrik, D. 2001. Trade Policy and Economic Growth: A Skeptic's Guide to the Cross-National Evidence. NBER Macroeconomics Annual 2000.

Rodrik, D. 2006. Goodbye Washington Consensus, hello Washington Confusion? A review of the World Bank's Economic Growth in the 1990s: Learning from a decade of reform. American Economic Association.

Sachs, J., and Warner, A. 1995. Economic Reform and the Process of Global Integration. Brookings Papers on Economic Activity, 1-118.

Spechler, M. 2002. Regional Cooperation in Central Asia. Problems of Post-Communism 49: 42-47.

Stepanyan, A., Roitman, A., Minasyan, G., Ostojic, D., and Epstein, N. 2015. The Spillover Effects of Russia's Economic Slowdown on Neighbouring Countries. Washington DC.

Stronski, P., and Ng, N. 2018. Cooperation and Competition: Russia and China in Central Asia, the Russian Far East, and the Arctic. In Carnegie Endowment for International Peace. URL: carnegieendowment.org/2018/02/28/cooperation-and-competition-russiaand-china-in-central-asia-russian-far-east-and-arctic-pub-75673. 
Sulamaa, P., and Widgren, M. 2004. EU-Enlargement and Beyond: A Simulation Study on EU and Russia Integration. Empirica 31: 307-323. DOI: https://doi.org/10.1007/s10663004-4090-4.

Tinbergen, J. 1962. Shaping the World Economy: Suggestions for an International Economic Policy. New York: Twentieth Century Fund. URL: http://repub.eur.nl/res/pub/16826/.

UN-OHRLLS. 2013. State of the Least Developed Countries. URL: http://unohrlls.org.

UNCTAD. 2007. Handbook of Statistics 2006-2007. New York and Geneva, United Nations Conference on Trade and Development: TD/STAT.31.

Viner, J. 1950. The Customs Union Issue. Chapter 4. In New York: Carnegie Endowment for International Peace (pp. 41-56). URL: carnegieendowment.org/2018/02/28/cooperation-and-competition-russia-and-china-in-central-asia-russian-far-east-and-arctic-pub75673

Vijayaraghavan, M., and Ward, W. A. 2001. Institutions and Economic Growth: Empirical Evidence from a Cross-national Analysis. Clemson University.

Wacziarg, R. 2001. Measuring the Dynamic Gains from Trade. World Bank Economic Review 15 (3): 393-429.

Wang, W. 2014. The Effect of Regional Integration in Central Asia. Emerging Markets Finance and Trade 50: 219-232.

Winter, L. A. 2004. Trade Liberalisation and Economic Performance: An Overview. The Economic Journal 114 (493). URL: https://onlinelibrary.wiley.com/doi/abs/10.1111/j. 0013-0133.2004.00185.x.

World Bank. 2010. The World Bank Annual Report 2010. Year in review. Washington D.C.: World Bank.

World Bank. 2015. Remittance Prices Worldwide. (WP/07/03). Washington, D.C.

World Bank. 2016a. Migration and Remittances Factbook 2016. Third Edition. Washington D.C.: World Bank.

World Bank. 2016b. World Development Indicators. World Bank, November. URL: http:// data.worldbank.org.

WTO - World Trade Organization. 2008. Regional Trade Agreements. URL: https://www. wto.org/english/res_e/publications_e/wtr08_e.htm. 